Pamiętnik Literacki 2021, 1, s. 131-161

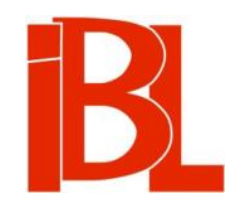

\title{
Żywa nauka Franciszka Siedleckiego
}

\author{
Artur Hellich
}




\section{2. $\begin{array}{lllllllllllllllllll} & \mathrm{M} & \mathrm{A} & \mathrm{T} & \mathrm{E} & \mathrm{R} & \mathrm{I} & \mathrm{A} & \mathrm{L} & \mathrm{Y} & \mathrm{I} & \mathrm{N} & \mathrm{O} & \mathrm{T} & \mathrm{A} & \mathrm{T} & \mathrm{K} & \mathrm{I}\end{array}$}

Pamiętnik Literacki CXII, 2021, z. 1, PL ISSN 0031-0514

DOI: $10.18318 / \mathrm{pl} .2021 .1 .9$

ARTUR HELLICH Uniwersytet Warszawski

ŻYWA NAUKA FRANCISZKA SIEDLECKIEGO*

Danucie Ulickiej

\section{Pół wieku za późno}

Oto wybrane zdania ze wstępu do zbioru szkiców Fragmenty, który powstał w roku 1934, a więc gdy bohater tego tekstu, Franciszek Siedlecki, miał 28 lat:

Sama forma prowadzi do geometrycznych kombinacji, co duszę ludzką otaczają zwałem zimnych kształtów niedopuszczających doń żadnych wzruszeń uczuciowych. Duch bez formy zagubia się w mglistych majaczeniach. Złączenie ducha i materii stwarza dzieło sztuki będącej w swej istocie symbolem tremendae majestatis, pierwiastka boskiego, źródła wszystkich fenomenów. [...] W każdym dziele sztuki doszukiwałem się symbolu pierwiastków boskich, bez względu na programy, szkoły lub kierunki, bez względu na czas i miejsce, gdzie powstało ${ }^{1}$.

Ale nie on je napisał. Ich autorem jest człowiek o tym samym imieniu i nazwisku (1867-1934): malarz, grafik, krytyk sztuki związany z secesją i symbolizmem, współpracownik „Chimery”. W roku publikacji Fragmentów Siedlecki (1906-1942) był szerzej nieznanym twórca jednego szkicu popularyzującego naukę o wierszu. Zanim, niespełna 8 lat później, w dramatycznych okolicznościach zmarł na gruźlicę, zdążył opublikować dwutomową książkę naukową, esej biograficzny i szereg rozpraw wersologicznych oraz krytycznoliterackich, w których dał się poznać m.in. jako niepohamowany krytyk właśnie takiej postawy wobec sztuki, jaką zaprezentowano w cytowanym ustępie: doszukiwania się w dziele „symbolu pierwiastków boskich” czy akcentowania roli „wzruszeń uczuciowych” w lekturze.

Jednak niezależnie od dzielących ich gruntownych różnic światopoglądowych i metodologicznych artysta i badacz nazywali się tak samo, obaj publikowali w międzywojniu, chociaż w innych czasopismach. Ten pierwszy był autorem Fragmentów, drugi - Fragmentów o Błoku. Pech chciał, iż do dzisiaj są myleni. W niedawnej biografii Juliana Tuwima napisano, że Balem $w$ operze, czytanym jeszcze w odpisach, zachwycał się „przejęty malarz i grafik Franciszek Siedlecki”" Tego błędu

* Artykuł powstał w ramach grantu NCN 2014/13/BHS2/00310 Wiek teorii. Sto lat polskiej myśli teoretycznoliterackiej. Za konsultacje, liczne krytyczne uwagi i sugestie bibliograficzne, które pomogły mi w napisaniu tego tekstu, chciałbym bardzo podziękować prof. Marii Prussak.

1 F. Si edle cki, Fragmenty. Warszawa 1934, s. [1-2].

2 M. Urban e k, Tuwim. Wylękniony bluźnierca. Warszawa 2013, s. 150. 
można by uniknąć dzięki ustaleniu dat (Siedlecki-artysta zmarł w 1934 roku, Bal $w$ operze powstał w 1936 roku). Ale nie tylko biografista Tuwima zaniechał weryfikacji faktów. Zapomniał o tym także autor hasła biograficznego $z$ największej internetowej encyklopedii, który przypisał zasługi literaturoznawcy jego imiennikowi, twierdząc, że grafik i malarz „Zwrócił uwagę dobrymi studiami z dziedziny poetyki (druk. w "Skamandrze", "Przeglądzie Współczesnym"), w których m.in. teoretycznie polemizuje z Zawodzińskim"3. A przecież w okresie publikacji tych tekstów (1935-1938) ilustrator „Chimery” już nie żył...

Naturalnie, literaturoznawcy rzadko cieszą się sławą porównywalną do pisarzy, artystów czy nawet wziętych krytyków, ale skala zapomnienia o Siedleckim mimo wszystko może zastanawiać. Wśród badaczy historii nauki polskiej o literaturze panuje zgoda, że autor Studiów z metryki polskiej zaliczał się w latach trzydziestych $\mathrm{XX}$ wieku do prekursorów nowoczesnego literaturoznawstwa, którą to nazwę skądinąd sam (jak widać $\mathrm{z}$ sukcesem) propagował ${ }^{4}$. Lektura jego tekstów, zachowanych listów, archiwaliów i wspomnień na jego temat nie pozostawia wątpliwości, że Siedlecki był organizatorem i inspiratorem ruchu teoretycznoliterackiego działajacego najpierw przy Kole Polonistów Studentów Uniwersytetu im. Józefa Piłsudskiego w Warszawie, a potem przy klubie dyskusyjnym, który zbierał się w salach Gimnazjum im. Królowej Jadwigi ${ }^{5}$. To m.in. $z$ inicjatywy Siedleckiego i pod jego redakcją powstały dwie publikacje najważniejsze dla polskiego literaturoznawstwa przedwojennego i zarazem stanowiące ewenement na skalę światową ${ }^{6}$ : Prace ofiarowane Kazimierzowi Wóycickiemu ${ }^{7}$, gromadzące teksty najwybitniejszych teoretyków na świecie, jak również (zniszczona w pożarze drukarni podczas okupacji) pierwsza na świecie antologia rosyjskiego formalizmu8 ${ }^{8}$. Rzeczywistej pozycji Sie-

Franciszek Siedlecki (1867-1934). Hasło w: Wikipedia, wolna encyklopedia. Na stronie: pl.wikipedia.org/wiki/Franciszek_Siedlecki (data dostępu: 20 IV 2020).

4 Zob. F. Sie dle cki, Biorę na siebie winę (1938). W: Pisma. Red. M. R. May e nowa, S. Żółkiewski. Warszawa 1989, s. 98-99.

5 Zob. np. fragment listu F. Siedleckiego do K. W. Zawodzińskiego (z 22 I 1934. Bibl. Narodowa. Archiwum Karola Wiktora Zawodzińskiego. Korespondencja K. W. Zawodzińskiego, t. 26, rkps 7419 III) dotyczący powstania serii wydawniczej „Archiwum Tłumaczeń z Teorii Literatury”, redagowanej przez młodego badacza: „po dwuletnim duszeniu Koła Polonistów o przystapienie do wydawania "Archiwum" wymogłem wreszcie przed niespełna rokiem, że zaczęto zbierać materiały [...]. Ale sprawa napotyka na [!] pewien opór czy też - mówiąc ostrożnie - na [!] "brak entuzjazmu" i niezliczone zastrzeżenia, a to niestety nie tylko z zewnątrz, ale nawet przez same Koło Pol. traktowana jest dość niechętnie (broszura wydana nakładem Koła, ale staraniem wyłącznie moim)".

$6 \quad$ Zob. D. Uli c ka, Rzut oka na nowoczesne polskie literaturoznawstwo teoretyczne. W: Wiek teorii. Sto lat nowoczesnego literaturoznawstwa polskiego. T. 1: Monografia. Warszawa 2020, s. 24, 85-86.

7 Prace ofiarowane Kazimierzowi Wóycickiemu. Red. M. Kri d l. Wilno 1937. Rola Siedleckiego jako rzeczywistego redaktora książki, negocjującego z redaktorem serii wydawniczej „Z Zagadnień Poetyki”, M. Kridlem, listę tekstów i ustalającego ich układ, wyłania się z korespondencji między nimi, zachowanej w wileńskim archiwum autora Wstępu do badań nad dziełem literackim (zob. zwłaszcza F. Si e d l e c ki, list do M. Kridla, z 1935 〈?〉. Lietuvos mokslu akademijos Vrublevskiu biblioteka. Rankraščiu skyrius, F. 115, vnt. 271, lap. 3-6).

8 W grudniu 1937, kiedy w opracowaniu była antologia Rosyjska szkoła formalna 1914-1939, planowana jako kolejna pozycja w serii „Archiwum Tłumaczeń z Teorii Literatury”, F. Siedlecki żalił się K. Wyce (list z 27 XII 1937. Bibl. Narodowa. Archiwum Kazimierza Wyki. Korespondencja 
dleckiego w nie mniejszym stopniu dowodzą jego wizjonerskie postulaty akcentujące konieczność reorganizacji nauki o literaturze w Polsce - badacz głosił m.in. potrzebę powstania Instytutu Badań Literackich ${ }^{9}$, biblioteki o profilu teoretycznoliterackim oraz powołania cyklicznych ogólnopolskich konferencji młodych badaczy literatury. Wszystkie postulaty, jak wiadomo, zrealizowano po jego śmierci. Do tej listy zasług wypada dopisać obmyślenie, wraz z Kazimierzem Budzykiem i Tadeuszem Mikulskim, kolegami z pracy w dziale starodruków Biblioteki Narodowej w Warszawie, planu powstania „Vademecum Polonisty”, w tej postaci nigdy wprawdzie nie zrealizowanego, ale wprowadzonego przez Mikulskiego do tajnych kursów polonistycznych - ich uczestnikiem był np. Tadeusz Borowski ${ }^{10}$.

Jako ważną postać dla polskiego literaturoznawstwa teoretycznego przed wojną postrzegali Siedleckiego również inni. Pierwszy pomysł wydania jego prac rozproszonych pojawił się już w 1946 roku: na ogólnopolskim zjeździe w Krakowie upomnieli się o to młodzi poloniści, postulując także wznowienie serii „Archiwum Tłumaczeń z Teorii Literatury" ${ }^{11}$. Równolegle wydanie jego pism planowali koledzy z Warszawy i Wilna - publikacji miały towarzyszyć rozprawy takich autorytetów, jak Roman Jakobson, Kazimierz Nitsch czy Manfred Kridl ${ }^{12}$. Ostatecznie nic z tego nie wyszło, ale problem upamiętnienia Siedleckiego co jakiś czas powracał. Na początku lat pięćdziesiątych XX wieku Maria Renata Mayenowa korespondowała w tej sprawie $z$ przebywającym już w Stanach Zjednoczonych Kridlem ${ }^{13}$. W liście ze stycznia 1960 Jakobson informował Mayenowa, że od Petera de Riddera czeka „na wieść o terminie wydania tomu Siedleckiego"14, a w kwietniu 1970 autorka Poetyki teoretycznej zapewniała: „Przygotowujemy reedycję Siedleckiego” ${ }^{15}$. O tym, że tom Pism ukaże się w Państwowym Instytucie Wydawniczym, wiedziano już

K. Wyki, t. 5, rkps akc. 18677): „Co do dalszych planów "Archiwum Tłumaczeń", to poza ponad 20-to arkuszowem [wyraz nieczytelny] Rosyjska szkoła formalna nic nie wiem, co będzie - może wyjdzie tom $Z$ pogranicza literatury i folkloru z przedmową Krzyżanowskiego, ale to nie ja już robię w ogóle wiążąc to wydawnictwo ze studencką organizacją, przysądziłem jego los: że po paru latach jako "stary" będę musiał "odejść", a tymczasem ani nie mam zaufania do ludzi młodych, niesprawnych zupełnie, którzyby tę imprezę po mnie odziedziczyli, ani nie chciałbym wypuścić $z$ rąk rzeczy, którą stworzyłem i którą sobie planowałem w ramach co najmniej 8-9 tomików. Nie wiem jednak, czy mi się uda nadal prowadzić ten "sklepik" - boć to i jak oderwać się od Koła Polon., to gdzie znów finansy? Itd. itd. [...]".

S. Żółki ew ski, Z historii IBL. „Biuletyn Polonistyczny” 1973, nr 49.

M. Kli m o w i c z, Tadeusz Mikulski. W zb.: Ksiega wspomnień o zmartych pracownikach powojennej polonistyki wrocławskiej. Red. M. Urs el. Wrocław 2002, s. 10-11. - T. B or ow s ki, Profesorowie i studenci. W: Pewien żotnierz. Opowieści szkolne. Warszawa 1947.

Z. W a s il e w s k i [i in.], Resumé 1-go po wojnie ZJAZDU OGÓLNEGO ZWIĄZKU KÓŁ POLONISTYCZNYCH P. M. A. - Kraków, 31 X - 4 XI 1946 r. Bibl. Narodowa. Archiwum K. W. Zawodzińskiego. Korespondencja K. W. Zawodzińskiego, t. 34, rkps 7419 III. Drugi z przywoływanych tu listów do tego adresata także pochodzi ze wskazanego zasobu archiwalnego.

Zob. M. R. May e n ow a, list do R. Jakobsona, z 27 X 1946. Massachusetts Institute of Technology, Mayenowa folder in the Jakobson papers MC-0072, box 44, folder 15. Pozostałe listy Mayenowej pochodzą $z$ tego samego folderu.

M. R. M a y e n ow a, list do M. Kridla (z początku lat pięćdziesiątych XX w.). Columbia University. Manfred Kridl Papers. Rare Books \& Manuscripts Library, series II, box 3.

R. Jak ob s on, list do M. R. Mayenowej, z 19 I 1960.

M. R. May e now a, list do R. Jakobsona, z 20 IV 1970. 
w 1984 roku $^{16}$, chociaż książka wyszła drukiem dopiero w roku 1989 - zatem blisko pół wieku po tym, gdy po raz pierwszy ją zaplanowano! Omówienie, dlaczego tom Siedleckiego tak długo nie był publikowany - oprócz przyczyn łatwych do wydedukowania (problematyczny stosunek do rosyjskiego formalizmu w kręgach partyjnych, wydarzenia Marca 1968, które uderzyły i w Stefana Żółkiewskiego, i w Mayenową, krzyżując wiele ich planów) - to temat na osobną rozprawę.

Wrażenie robią nazwiska uczonych wypowiadających się o uczonym $z$ uznaniem. Jakobson, z którym Siedlecki żywo korespondował przed śmiercią, nazwał go „wybitnym badaczem” i umieścił jego nazwisko obok Kridla jako reprezentanta „polskiej grupy" teoretyków literatury ${ }^{17}$. Kazimierz Wóycicki, prekursor nowoczesnych studiów nad literaturą i zarazem nauczyciel Siedleckiego, pisał, że „zgrzeszyłby niewdzięcznością", gdyby w przedmowie do swej ostatniej książki nie złożył podziękowań młodszemu koledze, ,którego żywy umysł, bogata wiedza i wprawiająca w podziw znajomość literatury przedmiotu przychodziły [...] [mu] niejednokrotnie z najżyczliwszą pomocą i zawsze oddziaływały pobudzająco" ${ }^{\prime 18}$. Ale dla młodego literaturoznawcy cenniejsza od tej kurtuazyjnej formuły musiała być uwaga zawarta w kolejnym zdaniu: „Terminologię zachowuję ustaloną przez Siedleckiego” 19 . Maria Dłuska, mimo ostrych $z$ nim polemik, dedykowała zmarłemu koledze po fachu swe Studia z historii i teorii wersyfikacji polskiej i wspomnieniu o nim poświęciła osobiste posłowie, akcentujące „fenomenalne zdolności i równie fenomenalne, żarliwe, nieomal religijne umiłowanie przedmiotu, który wybrał", a także określające Siedleckiego i nią sama jako „czcicieli wielkiej damy serca”, czyli wersologii ${ }^{20}$. Pozytywnie wypowiadali się o Siedleckim też Konstanty Troczyński ${ }^{21}$ oraz Kazimierz Wyka ${ }^{22}$, który widział w nim jednego $\mathrm{z}$ niewielu ciekawych autorów reaktywowanego w latach trzydziestych XX wieku „Skamandra” i który brał go w obronę przed nadmierną, jego zdaniem, krytyką ze strony Karola Wiktora Zawodzińskiego ${ }^{23}$.

Już po śmierci Siedleckiego wspomnieniowe szkice, bezcenne z punktu widzenia wiedzy biograficznej na jego temat, i analizy poświęcili mu np. Kridl ${ }^{24}$, Budzyk $^{25}$ oraz Aleksandra Okopień-Sławińska i Janusz Sławiński; ci trzeci w tytule swojego artykułu stawiali znak równości między zmarłym a „polskim formalizmem”26. Sie-

S. Żół k i e w s ki, Franciszek Siedlecki i początki strukturalizmu polskiego (sprawozdanie). „Rocznik Towarzystwa Naukowego Warszawskiego" t. 47 (1984), s. 41.

R. J a k o b s o n, Polish-Russian Cooperation in the Science of Language. W: Selected Writings. T. 2. The Hague - Paris 1971, s. 454-455.

K. Wó y cicki, Rytm w liczbach. Z 28 tablicami. Wilno 1937, s. [1].

Ibidem.

M. Dłu s ka, Studia z historii i teorii wersyfikacji polskiej. T. 1. Kraków 1948, s. 358-360.

K. Troczyński, Polonistyka najmłodsza. Refleksje po zjeździe. „Dziennik Poznański” 1935, nr z 29 XI, s. 2, 3.

K. Wy ka, rec.: F. Sie dle cki, Studia z metryki polskiej. Wilno 1937. „Ateneum” 1938, nr 4/5.

K. Wy ka, Czasopisma literackie (1938). W: Stara szuflada i inne szkice z lat 1932-1939. Oprac.

M. Urban ows ki. Kraków 2000, s. 511, 513.

M. Krid1, Franciszek Siedlecki. W zb.: Straty kultury polskiej 1939-1944. Red. A. Ordęga,

T. Terlecki. Glasgow 1945.

K. B u d zy k, O Franciszku Siedleckim wspomnienie. „Pamiętnik Literacki” 1946, z. 3/4.

A. Ok opień, J. Sławiński, O Franciszku Siedleckim i „polskim formalizmie”. „Twórczość” 1960, nr 10. 
dlecki jawi się jako jedna $\mathrm{z}$ istotniejszych postaci polskiego przedwojennego literaturoznawstwa także w świetle powstałej wiele lat później książki zbiorowej Tradycje polskiej nauki o literaturze ${ }^{27}$, gdyż nikomu nie poświęcono tyle uwagi i osobnych analiz, ile autorowi Studiów z metryki polskiej.

Ponawiam pytanie: dlaczego postać tak istotna dla polskiej humanistyki została dzisiaj, nie liczac wąskiego kręgu specjalistów, prawie zapomniana? Przyczyną, jak się wydaje, nie jest brak upamiętnienia, lecz upamiętnienie, o czym pisałem wcześniej, o pół wieku spóźnione i (co z tego również wynika) redukujące Siedleckiego do roli osobistości wprawdzie ważnej dawniej, ale niezbyt atrakcyjnej po latach.

Znakiem tego są już wspomnienia Budzyka, który przekonywał, że „Wiele z naukowej ścisłości zachowały do dziś z niczym ówcześnie nie dające się u nas porównać studia wersyfikacyjne Siedleckiego, choć niewątpliwie w pełni ich dzisiaj aprobować nie sposób”28. Data powstania tego szkicu (1950) jest wystarczającym uzasadnieniem takiego, a nie innego tonu wypowiedzi („Formalizm w nauce, a w praktyce społecznej - komunizm? Dziś to wydaje się dość dziwne, żeby nie powiedzieć - dziwaczne"29). Ale również w dwóch obszernych wprowadzeniach do wyboru Pism Siedleckiego z 1989 roku, pióra Żółkiewskiego i Mayenowej, zaprezentowano badacza jako zmierzającego w dobrym kierunku, lecz niewolnego od błędów. Te zaś błędy - pod warunkiem, że weźmie się pod uwagę kontekst czasu i miejsca jego działalności - należy mu wybaczyć.

Warto, choćby pokrótce, przeprowadzić krytyczną analizę omówień Żółkiewskiego i Mayenowej.

Otwierające książkę wspomnienie Żółkiewskiego tylko do pewnego stopnia dotyczy byłego kompana z Koła. Zaznaczmy, że artykuł O Franciszku Siedleckim ${ }^{30}$ jest rozbudowaną wersją szkicu wcześniejszego o dwa lata - zapowiedzianego jako „fragment większej całości” i poprzedzonego jeszcze odczytem z $1984 \mathrm{roku}^{31}$ - Do początków strukturalizmu polskiego ${ }^{32}$, w którym autor przedstawiał własną wizję rozwoju dyscypliny. Znalazło to odzwierciedlenie we wprowadzeniu do Pism; rozpoczyna się ono od bardzo obszernego omówienia, przyćmiewającego następujący po nim zarys sylwetki Siedleckiego, ogólnej sytuacji społeczno-politycznej, a zwłaszcza ekonomicznej, w której żył i tworzył bohater wprowadzenia. Pozostawało to nie bez związku z zainteresowaniami naukowymi Żółkiewskiego, socjologa życia literackiego, choć zarazem sugerowało, że, po pierwsze, Siedlecki powinien być rozpatrywany jako „wytwór” swoich czasów, a po drugie, że warunkiem właściwego zrozumienia i docenienia jego zasług jest uwzględnienie szerokiego kontekstu.

Dopiero po 20 stronicach obszernego wstępu Żółkiewski zaczyna pisać „o Franciszku Siedleckim”, choć do niektórych tez można mieć istotne zastrzeżenia.

\section{Warszawa 2008.}

28 Ibidem.

K. Bu d zy k, Pamięci Franciszka Siedleckiego. „Zeszyty Wrocławskie” 1950, nr 1/2.

S. Żółki ews ki, O Franciszku Siedleckim. W: F. Si edle cki, Pisma. Zebr., oprac. M. R. Mayenowa, S. Żółkiewski. Warszawa 1989.

Żół k i e w s ki, Franciszek Siedlecki i początki strukturalizmu polskiego.

S. Żółki ews ki, Do początków strukturalizmu polskiego. „Zeszyty Naukowe Wydziału Humanistycznego Uniwersytetu Gdańskiego. Prace Historycznoliterackie” 1987, nr 12/13. 
Np. do stwierdzenia, że „Centralnym problemem dla Siedleckiego był stosunek lingwistyki fonologicznej i strukturalizmu do fonologii” ${ }^{33}$. Słuszności tej tezy miał dowodzić - wyeksponowany w tomie - słynny list do Jakobsona, wysłany z Warszawy w 1941 roku, w którym autor z żarliwością podejmował zagadnienia metodologiczne. Żółkiewski wiele uwagi poświęca analizie tematów poruszanych w liście, punktując niekonsekwencje merytoryczne i pieczołowicie tłumacząc intencje zmarłego kolegi. Zapomina, że nie jest to świadomie spisany testament uczonego, ale żywa, emocjonalna reakcja na lekturę książki przesłanej Siedleckiemu przez Jakobsona - $z$ obszernej korespondencji dwóch literaturoznawców akurat ten jeden list się zachował. Ciężko już chory i żyjący w okupacyjnej nędzy uczony nie skonstruował wywodu ani przemyślanego, ani przygotowanego do druku, raczej więc nie powinno się traktować go jak tekstu reprezentatywnego dla dorobku. Reprezentatywny zresztą nie jest, bo - wbrew sugestii Żółkiewskiego - sprawy metodologii naukowej nie znajdowały się u Siedleckiego na pierwszym planie, czego dowodzi lektura całej jego spuścizny. Były natomiast ważne dla Żółkiewskiego i to, jak się wydaje, stanowi przyczynę ich nadreprezentacji.

Podobne wrażenie można odnieść po lekturze omówienia Mayenowej. Pierwsze 15 stronic tekstu Wersologia F. Siedleckiego i jej założenia teoretyczne wypełniają polemiki badaczki z tezami Romana Ingardena. Dalsza część jest zaś poświęcona rekonstrukcji koncepcji wersologicznych bohatera tomu i ich gruntownej krytyce z odnotowaniem, że mimo wszystko udało się Siedleckiemu wprowadzić naukę o wierszu na właściwe tory.

Zarówno Żółkiewski, jak i Mayenowa skupiali się na dorobku teoretycznym i poetologicznym Siedleckiego, pośrednio więc uzależniając atrakcyjność jego dzieła od trafności i aktualności jego koncepcji badawczych, a do tych, jak sami przekonywali, można było mieć uzasadnione zastrzeżenia. Potwierdza to układ tomu i wybór zawartości: do książki włączono wszystkie teksty akademickie i krytycznoliterackie, pominięto zaś poemat dla dzieci, który w całości nigdy nie ukazał się drukiem, a także publikowany w odcinkach esej biograficzny. Jedyne archiwalium, jakie uwzględniono (było ich więcej), to wspomniany list do Jakobsona. W konsekwencji z lektury tomu wyłania się niepełny obraz Siedleckiego: jako naukowca i krytyka, ale już nie jako poety, eseisty, stylisty i - zaryzykuję patetyczne określenie - nie jako człowieka. Oczywiście, gdyby Pisma ukazały się tuż po wojnie, jak na początku planowano, taki sposób prezentacji przedwcześnie zmarłego uczonego byłby uzasadniony i trafiony, choćby dlatego, że nawet sam przekrój podejmowanych przez niego problemów badawczych przedstawiałby go wtedy jako prekursora na skalę światową. Jednak 50 lat później radykalnie zmienił się kontekst, czyniąc tak dobrane, redagowane i skomentowane Pisma dziełem przynależącym mimo wszystko do poprzedniej epoki ${ }^{34}$.

34 Nie zmieniają tego nowsze opracowania dotyczące m.in. Siedleckiego. Ambicją monografii A. Ka rc z a (The Polish Formalist School and Russian Formalism. Kraków 2002), choć badacz wiele uwagi poświęca autorowi Studiów z metryki polskiej, jest nade wszystko rekonstrukcja historii powstawania szkoły formalistyczno-strukturalistycznej, a nie ukazanie Siedleckiego i jego kolegów z nowej, odświeżającej perspektywy. To samo można powiedzieć o monografii bohemisty P. Gi e r o w s ki e- 
Toteż celem przyjętym w tym artykule jest scharakteryzowanie Siedleckiego od nowa i bez redukcji, z uwzględnieniem elementów zazwyczaj pomijanych przez jego komentatorów i biografistów. Jedno z założeń Żółkiewskiego pragnę jednak podtrzymać. Chodzi o tezę o istnieniu metonimicznej przyległości między Siedleckim i jego twórczością - niedzielona jednak na naukową czy literacka - a polskim strukturalizmem (podobne założenie przyjęli Sławińscy w przywoływanym szkicu, tyle że oni mówili o „polskim formalizmie”). Sądzę, iż pisząc o Siedleckim, pisze się o modelu nowoczesnego literaturoznawcy (czy, szerzej, „intelektualisty kulturowego” ${ }^{35}$ ), który radykalnie zrywał $z$,najbliższą przeszłościa”” i programowo angażował się w sprawy aktualnego świata ${ }^{36}$ (w rzeczywistości powojennej model ten będzie realizowany w biografiach wielu wybitnych badaczy, a już przedtem miał niemałe grono wyznawców). Przez nowoczesnego literaturoznawcę rozumiem uczonego znajdującego się w metaforycznie rozumianym obszarze „pomiędzy” - Danuta Ulicka wskazuje na pięć możliwych interpretacji owego przyimka, dla mnie najważniejsze będą dwa $z$ nich: między literaturoznawstwem a literatura oraz między nauka a polityką ${ }^{37}$. Istotne jest to, że owe dwa sensy „bycia pomiędzy” (podobnie jak trzy pozostałe) nie sa niezależne od siebie, lecz stanowia splot ${ }^{38}$, co innymi słowy oznacza, że stosunku badacza do literatury wobec innych dyskursów nie sposób rozpatrywać w oderwaniu od jego stosunku do sytuacji polityczno-społecznej. Jeśli przyjrzeć się spuściźnie i działalności Siedleckiego pod kątem tych właśnie relacji, bohater niniejszego tekstu będzie się jawić nie jako jeden $z$ adeptów nowej metody, ale jako twórca $z$ wielu względów prekursorski i interesujący także dzisiaj.

g o (Struktury historii. O czeskim projekcie dziejów literatury na tle recepcji praskiego strukturalizmu $w$ Polsce. Kraków 2013, s. 131-132), który podkreśla pierwszorzędną rolę Siedleckiego w kształtowaniu się polskiego literaturoznawstwa teoretycznego, ale wspominając o liście polskiego uczonego do Jakobsona, w zasadzie powtarza to, co napisał na ten temat Żółkiewski. Dowodem, jak silnie fakt wyeksponowania słynnego listu wpłynął na późniejsze postrzeganie Siedleckiego i jego kolegów, jest passus z książki B. Ry ża (Koncepcja języka teoretycznoliterackiego strukturalistów polskich. Wrocław 2013, s. 77), który jedno, wyrwane z kontekstu zdanie Siedleckiego potraktował jako argument za teza, że członkowie przedwojennego Koła „postawy metodologicznej uczyli się właśnie od Żółkiewskiego", a później postawa ta rzekomo stała się punktem odniesienia dla powojennych strukturalistów, takich jak Janusz Sławiński. Przypomnijmy, że Siedlecki, dziękując Jakobsonowi za nadesłane lektury, napisał w tym liście, iż dały mu one „dużo do myślenia (przede wszystkim dzięki stałemu obcowaniu z Żółkiewskim, który mnie uczy mnóstwa rzeczy - właściwie wszystkiego! - i tresuje moje sumienie metodologiczne)" (F. Siedlecki, list do R. Jakobsona, z 3 VI 1941. W: Pisma, s. 75). Biorąc pod uwagę kontekst relacji, jakie łączyły polskich badaczy z Jakobsonem (tylko Siedlecki komunikował się z nim, i to jedynie listownie), a także mając w pamięci charakterystyczną dla autora Studiów z metryki polskiej skłonność do retorycznej przesady, która nierzadko graniczyła z ironią (znaną każdemu, kto czytał jego listy), nie sposób traktować tych słów całkiem serio i wprost. Wydaje się zaś, że Siedlecki po prostu zachwalał Jakobsonowi Żółkiewskiego, przy okazji subtelnie dystansując się od pryncypialności przyszłego hetmana „Kuźnicy”, „tresującego sumienia metodologiczne” swoich bliskich.

Ibidem, s. 96.

Ibidem, s. 114, 121-122.

Ibidem, s. 114. 


\section{Badacz jako autor}

Uzupełnienie portretu Siedleckiego o to, czego w nim brakuje, jest równoznaczne z przyjęciem perspektywy kulturowego spojrzenia na uprawianie nauki. Badania literackie, do których niewątpliwie zalicza się również wersologia, są jedną z odmian pisarstwa podejmowanego przez człowieka $z$ taką, a nie inną pozycją i świadomością klasową, mającego określoną biografię, która determinuje jego intencje, i sięgającego po pióro w konkretnym kontekście historycznym, politycznym oraz społecznym. Sztuczne wypreparowanie efektów pracy poznawczej od jednostki, która pracę tę podejmowała, może pomóc zachowaniu czystości dyscyplinarnej i tym samym podniesieniu społecznej rangi „profesjonalnych” badań. Jednak w przypadku Siedleckiego metoda ta przyczyniła się do utrwalenia jego dorobku - by posłużyć się jego własnym określeniem - jako „martwej nauki”39.

Pozwalam sobie na wypowiedzenie tych stwierdzeń, stanowiących credo niniejszego artykułu, tylko w celu zbudowania pomostu między podejściem Siedleckiego a moim własnym. Autor Studiów z metryki polskiej opisywał swoją postawę na różne sposoby i w wielu tekstach. Najprecyzyjniej zrobił to jednak (prawdopodobnie $^{40}$ ) nie on sam, ale Budzyk w posłowiu do drugiego zeszytu „Archiwum Tłumaczeń":

pionier jakiejkolwiek dyscypliny badawczej nie buduje założeń uprawianej przez siebie nauki, zamknąwszy się w czterech ścianach ze swymi naczelnymi aksjomatami i dyrektywami, lecz jest poza tym człowiekiem, którego działalność uwarunkowana jest zarówno stanem wiedzy na danym historycznym stopniu rozwoju, jak i wyznawanym wtedy światopoglądem ${ }^{41}$.

Nie mam wątpliwości, że stanowisko Budzyka podzielał także redaktor serii, w jakiej ukazało się posłowie. Dowodzą tego jego stwierdzenia zapisane dwa lata wcześniej, we wprowadzeniu do prezentacji dziejów polskiego wiersza metrycznego. Krytykując większość swych poprzedników, młody badacz wypowiadał się z niechęcią o "mętnych wodach tych przeróżnych subiektywnych normatywizmów" ${ }^{2}$ :

człowiek jest egocentrykiem i mierzy, ogląda, ocenia świat zewnętrzny pod kątem własnych swych nawyków, umiłowań, fobij. Poezję - ocenia według poetyki, w której wzrósł, wykształcił się artystycznie. Dlatego też tylu badaczy („badacz” jest również człowiekiem) szczyt wersyfikacji polskiej widziało w tasiemcach Przedświtu [...] $]^{43}$.

Siedleckiemu, buntowniczo nastawionemu do tradycyjnej pozytywistycznej filologii, marzyło sie „przełamanie owego egocentryzmu i zrozumienie dialektyki

F. Sied le cki, Martwa nauka (1936). W: Pisma, s. 92.

Posłowie nie zostało podpisane, co mogłoby stanowić wskazówkę, że jego autorem jest redaktor serii, czyli Siedlecki, skądinąd autor noty Od wydawców zamieszczonej w pierwszym zeszycie „Archiwum Tłumaczeń z Teorii Literatury”. Nawiasem mówiąc, jako tekst Siedleckiego potraktował to posłowie K. Wy k a (Problem i metoda 〈1938〉. W: Stara szuflada i inne szkice z lat 1932-1939, s. 251). Sam F. Si e d l e c ki (Studia Kazimierza Wóycickiego nad wierszem a nowe prady badawcze 〈1938〉. W: Pisma, s. 207) wskazywał jednak jako autora Budzyka, co należy chyba uznać za rozstrzygające.

[K. B u d zy k], posłowie w zb.: Z zagadnień stylistyki: Spitzer, Vossler, Vinogradov. [Red. F. Si ed le c ki]. Warszawa 1937, s. 158-159.

F. Si e d l e c ki, Z dziejów naszego wiersza (1935). W: Pisma, s. 169.

Ibidem. 
przemian historycznych"44. Ale dobrze zdawał sobie sprawę z własnych ograniczeń poznawczych. Toteż w następnym akapicie dopowiadał:

Nieogarniony splot czynników kształtuje nasze upodobania poetyckie i nasze poetyki - czy to pisane, czy to pośrednio zawarte w kontekstach żywych utworów poetyckich. Jeżeli wszelkie zewnętrzne kryteria zawodzą, pozostaje już chyba jedyna droga poznania poezji - poprzez analizę kontekstu poetyckiego, poprzez wyłuskaną zeń poetykę danego utworu, danego wiersza, danego metrum ${ }^{45}$.

Nawiasem mówiąc, możliwe, że do cytowanych właśnie słów nawiązywali Sławińscy w zakończeniu swego szkicu, zwracając uwagę, iż mistrzowie Siedleckiego, rosyjscy formaliści, tworzyli koncepcję języka poetyckiego, opierając się na awangardowych kierunkach w ówczesnej poezji, a koncepcje polskiego badacza „rodziły się w ścisłych związkach z zachowawczym nurtem poezji, na przekór dążeniom awangardy. Ten przykład wieloznaczności pewnych postaw może popsuć humor niejednemu specjaliście od wykrywania prostych uzależnień" ${ }^{6}$. Artykuł kończył się tym intrygującym spostrzeżeniem, ja chciałbym je uczynić punktem wyjścia. Dlaczego w przypadku Siedleckiego owo „proste uzależnienie” nie zachodzi? Co czytał i jak czytał? Co oglądał, co go poruszało? Jaki miał stosunek do nauki, a jaki do literatury? Jak pisał? Innymi słowy: jaki był Siedlecki?

Na szczęście zachowało się relatywnie sporo materiałów - wspomnień, listów, dokumentów, intrygujących spostrzeżeń porozrzucanych w jego tekstach - które pozwalają przedstawić go jako człowieka $z$ krwi i kości. Również w sensie dosłownym. Wiadomo np., że w momencie przyjęcia na studia był bardzo szczupły i nie cieszył się dobrym zdrowiem (ważył 56,5 kg przy 168 cm wzrostu, w wojsku przydzielono mu kategorię $\mathrm{C}^{47}$ ). Włosy koloru ciemny blond, nos „proporcjonalny”, usta „mierne”, broda „okragła”, a twarz „podłużna”48. Kridl wspominał, że z wielkich, czarnych oczu „żyjącego prawie w ubóstwie” „chudego literata”, niedbającego „o wygody i przyjemności, nie szanującego zdrowia”, biła „pasja ukryta” 49 . Cierpiał na ostre ataki astmy, zakłócające mu pracę; bagatelizował je, ironizując w liście do przyjaciela, że już miał skończyć „à la Proust - w ataku astmy, a nie w napisaniu À la recherche..." ${ }^{0}$. Od Francji, do której żywił „dużo wątpliwości i zastrzeżeń” (podczas stypendialnego pobytu w Paryżu „nic właściwie nie robił”, „dużo się wylegiwał - taka jakaś prostracja”) ${ }^{51}$, wolał Warszawę, o ile odbywały się w niej jakieś ciekawe wydarzenia naukowe, a zwłaszcza chyba rodzinne Górzno, położone na granicy rezerwatu przyrody. Spędzał tam wakacje z ojcem, braćmi i zaprzyjaźnionym Dawidem Hopensztandem, z którym wyprawiał się na kilkunastokilometrowe wy-

Ibidem.

Ibidem, s. 169-170.

Okopień, Sławiński, op. cit., s. 106.

Odpis książeczki wojskowej F. Siedleckiego, z 5 IX 1929. Archiwum Uniwersytetu Warszawskiego, 651 - 1442016 - teczka RP 30.495.

Ibidem.

Krid1, op. cit., s. 239.

F. Si edle cki, list do W. Grodzieńskiej i S. Pollaka, z 8 I 1937. Muzeum Literatury im. A. Mickiewicza w Warszawie. Dział Rękopisów. Korespondencja Seweryna Pollaka, nr inw. 3676, t. 28. Cytowana dalej korespondencja kierowana do wskazanych osób pochodzi z tego samego tomu.

F. Si e dle cki, list do W. Grodzieńskiej i S. Pollaka, z 15 XII 1937. 
cieczki po gęstwinach leśnych i prowadził wielogodzinne dyskusje ${ }^{52}$. Nakłoniony przez Juliana Krzyżanowskiego do przyjęcia stypendium na pobyt naukowy w $\mathrm{Pa}$ ryżu (sam bodaj nigdy tego nie chciał), chodził po moście Aleksandra i „zaglądał obojętnie do skrzynek z książkami” ${ }^{3}$. „Oczywiście zacząłem poszukiwania ros. wyczerpanych (przede wszystkim moich fachowych)", relacjonował Sewerynowi Pollakowi i Wandzie Grodzieńskiej ${ }^{54}$. Dopominał się o wieści z Warszawy, irytował się odcięciem od codziennych spraw, które przedtem całkowicie go pochłaniały. Upływ czasu uprzyjemniały studentowi wizyty w restauracji „Węgierskiej” przy ulicy Mazarin, gdzie do potraw podawano dużo papryki, a na zasuniętym krześle obok spał jego ulubiony kot, nazywany przez kolegów ze stypendium „kotem Siedleckiego" 55 .

„Zesłany” na francuskie stypendium, młody badacz pochylał się nad notatkami, które prowadził „nerwowym, neurastenicznym pismem” ${ }^{56}$. Tak wyglądają również wysyłane przez niego karty pocztowe, czasem prawie nieczytelne, „obyczajem Siedleckiego nie mające początku i gubiące się w dopiskach" ${ }^{57}$. Bodaj ten sam rys osobowości dostrzegał w nim Kridl, charakteryzując go jako na co dzień cichego i skromnego młodzieńca, ceniącego rzetelną pracę, który w momencie chwycenia za pióro stawał się ostry, surowy i sarkastyczny ${ }^{58}$. Siedlecki zapalał się, nie pohamowywał w krytyce, wypowiadał pryncypialne sądy, miał skłonność do obrażania się na innych. Widać to w jego tekstach, które bardzo rzadko przypominaja uporządkowany, bezosobowy, zrygoryzowany formalnie wywód, jaki zwykło się kojarzyć z patronami polskiego strukturalizmu. Autor Martwej nauki dyskutował z cudzymi koncepcjami wersologicznymi, jakby wykłócał się z żywym człowiekiem o sprawy największej wagi. Nie chciał lub nie potrafił ukryć osobistego stosunku do przedmiotu badań, więc w celu zwiększenia ekspresji wypowiedzi doprawiał wywody retorycznymi i literackimi przyprawami: sięgał po epitety, metafory, wykrzyknienia. Tę właściwość jego pisarstwa naukowego doceniano po jego śmierci (i ona przyciagga do niego również dzisiaj) - obok cytowanej już Dłuskiej, na osobisty wymiar „pisania o średniówce” zwracała uwage Jadwiga Sawicka ${ }^{59}$, wcześniej Sławińscy odnotowywali, że esej o Tadeuszu Peiperze „zawiera w sobie cały poemat na cześć metrum" 60 .

Osobisty ton przebijający $\mathrm{z}$ tekstów Siedleckiego może sugerować, iż w uprawianiu wersologii nie chodziło jedynie o wersologię. Za jej pośrednictwem badacz odnosił się do spraw ogólniejszych, które traktował z największą powagą. Wskazują na to zwłaszcza listy, w których bronił swoich zajęć badawczych, podkreślając rzeczywistą motywację ich podjęcia. Wyce tłumaczył się:

Zob. D. Hopen s z t and, list do W. Grodzieńskiej i S. Pollaka, z 1933 (?).

T. Mikulski, Buka i Wowa. „Zeszyty Wrocławskie” 1950, nr 1/2.

Sie dle cki, list do Grodzieńskiej i Pollaka, z 15 XII 1937.

Mikulski, op. cit., s. 74 .

Ibidem.

Ibidem, s. 75.

Zob. przypis 49 .

J. S a w i c k a, Franciszek Siedlecki, czyli o substracie wersyfikacji polskiej. W zb.: Tradycje polskiej nauki o literaturze, s. 61.

Okopień, Sławiński, op. cit., s. 105. 
nie chodzi wyłącznie o to, czy średniówka jest po 5-ej, czy po 15-ej sylabie - pozostaja jeszcze ogólniejsze sprawy, tendencje naukowe, zagadnienia metodologiczne, a te przecież widoczne i jasne dla każdego, kto c h ce wiedzieć, a nie tylko dla „nudziarza-średniówkowca”61.

Tę samokrytykę i zarazem samoobronę warto czytać w odniesieniu do tez przedstawionych w płomiennej Martwej nauce, drukowanej w komunizującym (i wkrótce zamkniętym przez sanacyjne władze) czasopiśmie „Lewar”, którego Siedlecki był jednym $\mathrm{z}$ redaktorów. $\mathrm{W}$ eseju tym badacz wychodził od tezy o sztuczności podziału między „pracą teoretyczną a twórczością artystyczną”. Istnienie takiego podziału głosili, jego zdaniem, „burżuazyjni teoretycy literatury”, sarkastycznie nazwani przez niego „kapłanami Czystej Nauki”"62:

kiedy [ich] pracy nie przyświeca żadna nadzieja, że [...] wstąpi ona jednak pod strzechy życia, zutylitaryzuje się w ostatecznej konsekwencji [...], [wtedy] rosną, piętrzą się, puchną może Bogu na chwałę, ale z pewnością ludziom nie na pożytek piramidy dzieł nieczytanych, niepotrzebnych, poczętych w rezygnacji z jakiejkolwiek użyteczności, a częstokroć wręcz z ambicją zupełnej bezużyteczności ${ }^{63}$.

Właśnie to założenie przyjęte w Martwej nauce: że istnieje naturalny związek między akcentowaniem społecznego (utylitarnego) wymiaru uprawiania nauki o literaturze a przekonaniem o komplementarności poznania naukowego i literackiego, wydaje się fundamentalne dla zrozumienia zarówno Siedleckiego, jak i „początków strukturalizmu polskiego".

Niewykluczone, że za sprawą wspominanego listu do Jakobsona mógł utrwalić się wizerunek Siedleckiego jako żarliwego neopozytywisty pokpiwającego z literatów i utożsamianych $z$ nimi przedstawicieli idiografizmu. Nawiązuję tu do pojawiającej się w liście argumentacji, że zadaniem naukowca nie jest wszechogarnianie po Bergsonowsku rozumianej, ,płynnej” rzeczywistości, ponieważ „pod tym względem najwspanialszy uczony zostanie zdystansowany przez byle wizjonera, artystę, czasem renomowanego głupca"64. Jednak wbrew wrażeniu, które można odnieść po lekturze tych słów, Siedlecki wcale nie gardził literatami jako partnerami w poznaniu i potencjalnymi współpracownikami. Przeciwnie, cenił ich zdolność do „wszechogarniania” - właśnie dlatego, iż niejednokrotnie udawało im się opisać świat celniej od uczonych, generujących abstrakcyjne formuły w sterylnej przestrzeni gabinetu. Dość powiedzieć, że jako argument za ważną dla Siedleckiego koncepcją transakcentacji metrycznej on sam wymieniał fakt, iż podobną teorię kilka lat wcześniej skonstruował (w rozmowie prywatnej) Leonard Podhorski-Okołów. Zastanawiające,

Si e d le ck i, list do Wyki. Z kolei Pollakom - po obronie pracy magisterskiej, która stała się podstawą jego książki autorskiej - żalił się: „przy tej mojej wersologii grozi mi coraz poważniej zupełny analfabetyzm" (F. Si e d le cki, list do W. Grodzieńskiej i S. Pollaka, z 29 VIII 1936).

62 Siedlecki, Martwa nauka, s. 92-93.

63 Ibidem, s. 93. Nb. w bardzo podobnym tonie, ponad 60 lat później, wypowiadał się J. Sła wi ń s k i (Poniewczasie. W zb.: Krytyka i krytycyzm w nauce. Red. H. Żytkowicz. Warszawa 1998, s. 95-97), który zajmował wówczas w polskim literaturoznawstwie teoretycznym taka pozycję, jaka bez wạtpienia zajmowałby po wojnie Siedlecki, gdyby nie zmarł w okresie okupacji. Autor Tekstów i tekstów, krytykując „nadprodukcję rzeczy niepotrzebnych” w literaturoznawstwie, pytał retorycznie: „Jakiż Waligóra odważyłby się zmagać z tą monstrualną górą zbytecznej makulatury?” 
konstatował z pewną zaczepnością Siedlecki, „że doszedł do niej nie "uczony w piśmie" filolog, lecz poeta"65.

Dopiero w kontekście założenia o komplementarności poznania naukowego i artystycznego staje się jasne, na czym miałaby polegać postulowana przez Siedleckiego utylitaryzacja nauki o wierszu. Nie sądzę, że autor Studiów z metryki polskiej wierzył, iż badanie chwytu celowego zaburzenia rytmu, obnażającego strukturę utworu poetyckiego, może jakkolwiek wpłynąć na otaczająca go rzeczywistość społeczno-polityczna, choć oczywiście istnieje analogia między odnawiającą znaczenia dezautomatyzacja percepcji czytelniczej a odmieniająca stosunki społeczne rewolucją, której Siedlecki pragnął ${ }^{66}$. Dużo bardziej prawdopodobne wydaje się jednak to, że przez utylitaryzację badań wersologicznych rozumiał uczynienie ich przydatnymi, w pierwszej kolejności, dla szeroko rozumianych „ludzi pióra”, poetów i tłumaczy, takich jak właśnie Podhorski-Okołów czy Tuwim, którzy transferowali ceniona przez Siedleckiego kulture rosyjską do Polski i korzystali z wypracowanych w niej wzorców (stąd nacisk na wymiar praktyczny prowadzonych studiów). W drugiej kolejności zaś dla czytelnika zainteresowanego poezją, który dzięki zapoznaniu się z koncepcjami teoretycznymi mógł lepiej zrozumieć utwór literacki i głębiej przeżyć jego lekturę.

Chcąc spełnić te założenia, Siedlecki nie zamierzał ograniczać się do roli „nudziarza-średniówkowca”. Bywał eseistą, stylistą, tłumaczem poezji, a także poetą. Wszystkie odgrywane przez niego role nie istniały niezależnie od siebie, lecz interferowały ze sobą i nawzajem się oświetlały. Jako poeta Siedlecki testował teorię języka poetyckiego, którą znał jako badacz, w czym zresztą naśladował starszych kolegów zza wschodniej granicy. W sztuce dostrzegał i cenił to, co potrafił opisać teoretycznie. Nie wydaje się, że któraś z ról była ważniejsza od innych, choć jako wersolog osiaggnął znacznie więcej niż jako poeta.

Wbrew cytowanemu już twierdzeniu Sławińskich, polski uczony wcale też nie odróżniał się zasadniczo od swoich rosyjskich mistrzów w doborze lektur, na których materiale wypracowywał koncepcje teoretyczne. Autorzy eseju O Franciszku Siedleckim $i$ „polskim formalizmie” pisali, że bohater ich studium bazował na „zachowawczym nurcie poezji”. Mieli na myśli Skamandrytów, których oni sami, jak wolno sądzić, cenili mniej niż Awangardę krakowską. Żeby jednak oddać sprawiedliwość Siedleckiemu, należałoby powiedzieć, że cechowała go wszystkożerność

F. Siedlecki, Studia z metryki polskiej. Cz. 2: Problem transakcentacji metrycznej $w$ wierszu polskim. W: Pisma, s. 443.

66 Na istnienie tej analogii wskazuje np. prozopoetycki fragment eseju F. Si e d le ck k e go lOd dwóch do pięciu lat 〈1939〉. W: jw., s. 109) o książce K. Czukowskiego, w którym badacz daje się poznać nie tylko jako naśladowca W. Szkłowskiego (przetłumaczył jego Wskrzeszenie słowa), lecz także ukryty literat: „Obojętne, zgrubiałe palce nie wyczuwają misternego rysunku, wyciśniętego na monecie, niewidzacy wzrok prześlizguje się po nim ospale, jak ospale prześlizguje się po beznadziejnej szarzyźnie biurowych przedpołudni, po murze sterczącym przed oknem mieszkania, po wypłowiałej tapecie małżeńskiej sypialni, po całej skostniałej martwocie ubogich powszednich dni. Tylko poezja, rewolucja i inne kataklizmy zdolne są przełamać w nas klątwę automatyzacji, odpowszednić spowszedniałą rzeczywistość, odrodzić zamarły dynamizm kontaktu człowieka ze światem. Sprawić, że znów stają się wyczuwalne kanty stołu, rysunek na miedziaku, kształt słowa, i że życie nabiera życia, sensu, wartości”. 
poznawcza połączona z gustem egalitarnym, skłaniającym do poświęcania uwagi w równym stopniu sztuce głównonurtowej, dziełom z kanonu literatury światowej, jak i zwykle lekceważonym przez „poważnych” badaczy tworom kultury popularnej i użytkowej. Jeden $z$ towarzyszy paryskiej niedoli wspominał, że geneza poematu dla dzieci napisanego przez Siedleckiego wiązała się z... banerem reklamowym, który w maju lub czerwcu 1938 zawisł na stacji paryskiego metra nieopodal ulicy Lamandé, gdzie mieszkał polski stypendysta. Dzień w dzień oglądana przez Siedleckiego grafika reklamujacca sklep meblarski na Montmartrze przedstawiała idące przez las dwa drewniane stworki, ujęte komicznie pod rękę. Pod nimi znajdował się francuski napis: „Bois dur et bois joli [Twarde drewno i ładne drewno]”67. Zachwycony pomysłowością twórców baneru, Siedlecki postanowił nadać stworkom imiona, Buka i Wowa, a następnie uczynić je bohaterami (bohaterkami?) swojego poematu ${ }^{68}$.

Już sam akt (choćby tylko symbolicznego) ożywienia słowa, którego dokonał wzorem twórców paryskiej reklamy, wskazuje na podstawowe źródło inspiracji. „Jeśli człowiek współczesny zapełnia opuszczone wody rzek stadami ryb, to językołówstwo daje prawo zaludnić nowym życiem, wymarłymi lub nie istniejaccymi słowami zubożałe wody języka" - pisał jeden z poetyckich mistrzów Siedleckiego, Wielemir Chlebnikow ${ }^{69}$. W grudniu 1937, w paryskiej księgarni rosyjskiej, polski stypendysta kupił poświęconą jego twórczości broszurę autorstwa Jakobsona („85 groszy - to warto!”70); dzieła genialnego Rosjanina znał już zresztą wcześniej. Chlebnikowa, jak wiadomo, interesowało brzmienie mowy - w nim zwłaszcza, choć nie jedynie, upatrywał źródeł sensu, który winien być przywracany przez poetę, przypominającego dziecko bawiące się językiem (,słowo - to lalka z dźwięków, słownik - to zbiór zabawek"71). Wydaje się, że ów spontaniczny akt kreacji dostrzegł Siedlecki na paryskim banerze. Chwytliwe hasło reklamowe zespalało w jednym szeregu dwa ekwiwalentne człony - twarde drewno i ładne drewno - ujawniając ich nieoczekiwaną odpowiedniość ${ }^{72}$. W konsekwencji slogan przestawał być wyłącznie perswazyjnym komunikatem i zamieniał się w poezję; składające się na niego słowa zaczynały żyć nowym życiem, co ilustrował wizerunek drewnianych stworków idących pod rękę.

Dostrzegając literackość w - na pozór - tak nieoczekiwanych miejscach, jak reklama firmy meblarskiej, Siedlecki uczył się nie tylko od Chlebnikowa, lecz również od Władimira Majakowskiego, układającego rytmiczne slogany polityczne i społeczne oraz reklamy umieszczane na plakatach, doskonale zresztą znane Ja-

Mikulski, Buka i Wowa, s. 75.

F. Si e d l e c ki, Muzykantów było sześciu. Ballada o liskach. „Zeszyty Wrocławskie” 1950, nr 1/2, s. 77 .

W. Chlebnikow, Nasza postawa (1920). W zb.: Włamanie do Wszechświata. Poezja i proza. Wybór, przekł. A. Kamieńs ka, J. Ś piew ak. Kraków 1972, s. 104-105.

Si ed le c ki, list do Grodzieńskiej i Pollaka, z 15 XII 1937.

Chlebnikow, op. cit., s. 105.

Autoteliczny, a więc literacki wymiar sloganu mógł być ponadto konstytuowany przez homonimiczność zawartą w obu członach opozycji: („,bois dur” to po prostu 'twarde’, czyli porządne i stabilne 'drewno', ale też 'drewno liściaste', „bois joli’ zaś to zarówno 'ładne drewno', jak i francuska nazwa krzewu, który w Polsce znamy pod nazwą „wawrzynek wilczełyko” - ciekawe, czy użycie tutaj miana „Wowa” jest inspirowane aliteracją zawartą w polskiej, jakże poetyckiej nazwie tej rośliny). 
kobsonowi, który 20 lat później opisywał funkcję poetycką m.in. na przykładzie sloganu wyborczego Dwighta Eisenhowera („I like Ike”). Z rosyjskimi teoretykami dzielił Siedlecki zainteresowanie kultura popularna, zwłaszcza kinematografią. Wbrew wspomnieniu kolegi $\mathrm{z}$ pobytu w Paryżu, nie ograniczał się do oglądania filmów „awangardowych” 73 . Wedle jego własnej relacji, interesowało go po prostu wszystko, co można było zobaczyć wówczas w kinie - widział więc zarówno Marsyliankę Jeana Renoira, jak i Droge powrotna Jamesa Whale'a, wybierał się także na retrospektywny pokaz filmów Charliego Chaplina i z niecierpliwością czekał na pierwszą „długometrażówkę Disneya”74. Nawiasem mówiąc, do Królewny Śnieżki i siedmiu krasnoludków, bo o tym filmie mowa, nawiązywał rok później w eseju dedykowanym Tuwimowi ${ }^{75}$.

Ale podstawowym punktem odniesienia była dla Siedleckiego poezja. Nie da się zaprzeczyć, że wśród polskich autorów najwyżej cenił „starych metryków”: Tuwima, Jarosława Iwaszkiewicza, Jerzego Lieberta, Mieczysława Jastruna, Antoniego Słonimskiego czy Kazimierza Wierzyńskiego ${ }^{76}$. W ich twórczości bowiem odnajdywał najpełniej realizującą się, opisywaną przez Wiktora Szkłowskiego „technikę dezautomatyzacji”, którą uznawał za poruszającą dla czytelnika „wychowanego na wierszu futurystów, formalistów, awangardzistów, na najnowszej poezji czeskiej, polskiej lub rosyjskiej"77 (w ten sposób określał samego siebie). Polskiego i włoskiego futuryzmu, w przeciwieństwie do rosyjskiego, nie ceni1 ${ }^{78}$, ponieważ jego zdaniem do wielkiego Chlebnikowa bliżej było Tuwimowi niż np. Aleksandrowi Watowi.

Trzeba to powiedzieć dobitnie: Siedlecki był rusofilem i zarazem jednym z lepszych w Polsce znawców poezji rosyjskiej pierwszych dekad XX wieku, analitykiem jej przemian od symbolizmu po akmeizm i futuryzm (dowodza tego Fragmenty o Błoku i esej Wielka literatura dla małych). Fascynacja kultura rosyjską wyznaczała Siedleckiemu kręgi znajomości - określała pole odniesień literackich w rozmowach z Tuwimem, Podhorskim-Okołowem i Zawodzińskim ${ }^{79}$; stanowiła temat

W. W eintra u b, O wspótczesnych i o sobie. Kraków 1994, s. 29.

F. Sie dle c ki, listy do W. Grodzieńskiej i S. Pollaka, z 15 XII 1937 i z 1 I 1938.

Zob. F. Si ed le cki, Od dwóch do pięciu lat, s. 110: „A macocha (opowiada Elżunia o Disneyu) popatrzyła do takiego lusterka i woła: "Wiercidło, wiercidło! kto jest najpiękniejszy na świecie?"”

Sam krytyk tak wyznawał (F. Siedlecki, O swobode wiersza polskiego 〈1938〉. W: Pisma, s. 157).

Ibidem, s. 151.

Zob. F. Si e d le cki, Roman Jakobson i nowa lingwistyka. W: jw., s. 85: „[w Rosji] futurysta nie jest clownem (jak u nas) ani szarlatanem (jak we Włoszech), lecz wielkim, bardzo wielkim poetą, jak Chlebnikow. Gdzie z grona futurystów wychodzą światowej sławy uczeni. Gdzie poważny profesor chwali się, że "jest człowiekiem noszącym pod połą żółty sztandar futurystów" (Szkłowskij)”. Drogi Siedleckiego z Zawodzińskim, jak wiadomo, w pewnym momencie się rozeszły, ponieważ, chociaż był on wytrawnym znawcą kultury rosyjskiej, absolwentem petersburskiego uniwersytetu i kolegą $\mathrm{z}$ roku m.in. W. Żyrmunskiego, zdecydowanie bardziej cenił poezję symbolistyczną niż futuryzm, nie dzielił także zachwytów Siedleckiego nad - inspirowanym chwytem udziwnienia Szkłowskiego, a opisywanym przez młodszego kolege - zabiegiem transakcentacji w wierszu. Jak przekonywał: „"unaocznianie struktury metrycznej“ za pomocą zamącenia metrum, powiększanie smaku metrum przez jego psucie, przypomina legendarnych smakoszów smarujących talerz asafetydą, aby bardziej napawać się smakowitą wonią potraw" (K. W. Zaw odzińs ki, Nowe księgi o wierszu polskim. „Życie Literackie” 1938, z. 4, s. 142). „Cały ten artykuł mógłbym bez trudu ułożyć w jambach" - ripostował Si e d l e c ki (O swobodę wiersza polskiego, s. 165-166) i zaznaczał, 
dialogów - o przekładach liryki na język polski - z Pollakiem, Sergiuszem Kułakowskim czy Kazimierzem Andrzejem Jaworskim ${ }^{80}$; a o twórczości formalistów - z Hopensztandem. Poetą, który łączył Siedleckiego zarówno z rusofilami z jego pokolenia, jak i tymi z poprzedniej generacji, był Aleksander Błok (jego Jesienna miłość, wraz z Pollakiem i Podhorskim-Okołowem, młody uczony przetłumaczył ${ }^{81}$ ). Jednak, wbrew sugestii Żółkiewskiego, autor Jambów stał się badaczowi bliski nie dlatego, że Siedlecki wolał tradycyjna poezję symbolistyczną, z jakiej słynął wczesny Błok, od „konstruktywistów czy Majakowskiego lub Zabołockiego” ${ }^{82}$. W rozdarciu Błoka, który przebył dramatyczną drogę od symbolizmu, przez poezję rewolucyjną, po zawiedzenie samą rewolucją, Siedlecki dostrzegał, jak się wydaje, bardziej uniwersalna historie jednostki wrażliwej i czułej na dokonujące się w trakcie jej życia gruntowne przemiany społeczne i polityczne, niezdolnej zharmonizować swojego losu $\mathrm{z}$ zewnętrznym światem (do tej sprawy jeszcze wrócę). $\mathrm{W}$ tym sensie można powiedzieć, że autor Studiów z metryki polskiej patrzył nie tylko na polską poezję, lecz także na ówczesną sytuację Polski i Polaków w ogóle, przez pryzmat rosyjskiej kultury i doświadczeń rosyjskich twórców, którzy byli dla niego szczególnie istotni.

\section{Siedlecki a Tuwim}

Spośród „rusofilskich” kontaktów Siedleckiego relacja z Tuwimem zasługuje na osobna uwagę ${ }^{83}$. Nie wiadomo, jak się poznali, ale nietrudno o uzasadnione domysły. Bardzo możliwe, że za pośrednictwem Seweryna Pollaka, bliskiego przyjaciela Siedleckiego, który w 1925 roku zwrócił się do autora Sokratesa tańczacego z prośbą o ocenę swoich wierszy, a później został zatrudniony do porządkowania prywatnej biblioteki poety ${ }^{84}$. Tuwim był znany $z$ tego, że otaczał początkujących twórców taką opieka, jakiej sam niegdyś zaznał od Leopolda Staffa. Zresztą w okresie studiów zaliczał się do członków Zarządu Koła Polonistów (pełnił funkcję bibliotekarza), potem przekształconego w organ, do którego należała przyszła żona Pollaka, wspo-

że nie uczyniłoby to jednak jego eseju wielka poezją. Na co z kolei reagował K. W. Za w od ziń ski (Liryka polska w dobie jej kryzysu. „Przegląd Współczesny” 1939, nr 206, s. 9), rozmijając się wszakże z sensem wypowiedzi Siedleckiego i nie doceniając jego Fragmentów o Błoku: „rozpoetyzowane studia Siedleckiego o Błoku nie byłyby i w jambach świetną poezją". Nie dziwne, że w liście do M. Kridla (z 6 VI 1936. Lietuvos mokslų akademijos Vrublevskiu biblioteka. Rankraščiu skyrius, F. 115, vnt. 269, lap. 1) zarzucał F. Si e d le c ki Zawodzińskiemu, iż mimo że obaj „uczyli się od Rosjan”, on sam „poszedł w lekturze swej dalej”, podczas gdy jego starszy kolega „utknął na francuskich normatywistach".

K. A. Jaworski w powojennym numerze „Kameny” (1946, nr 8-10), poświęconym A. Błokowi, przedrukował większą część Fragmentów o Błoku Siedleckiego. Później wspominał też, że wraz z redaktorami „Kameny” brał Siedleckiego, jako entuzjastę twórczości radzieckiej, w obronę przed krytyką, która spływała na autora Studiów z metryki polskiej z tego powodu (K. A. J a w o r ski, W kręgu „Kameny”. Lublin 1965, s. 179).

81 A. Bło k, Jesienna miłość. W: Dwa wieki poezji rosyjskiej. Antologia. Red. M. J a str u n, S. Polla k. Warszawa 1954, s. 409-410.

83 Sugerowano to już wcześniej - zob. S a w i c ka, op. cit., s. 65-66.

84 Urbanek, op. cit., s. 96. 
mniana już Grodzieńska, a także Siedlecki. W miesięczniku „Pro Arte et Studio”, za czasów Tuwima prowadzonym przez Koło Polonistów, poeta publikował przekłady m.in. Błoka.

Z lektury listów Siedleckiego można wywnioskować, iż Tuwim był dla niego twórca niezwykle ważnym, wręcz otaczanym kultem, ale nie traktowanym jako niedostępny bóg literatury, do którego aż strach zwrócić się z pytaniem. Przeciwnie, wiadomo, że już w 1934 roku współpracowali ze sobą, choć ostatecznie sprawa zakończyła się fiaskiem. Badacz poprosił autora Balu w operze o przełożenie tekstów Aleksandra Puszkina, cytowanych przez Wiktora Żyrmunskiego we Wstępie do poetyki, wydanym w pierwszym zeszycie „Archiwum Tłumaczeń”; „odpowiedział nam po paru miesiącach, że przetłumaczyć ich nie zdołał”, żalił się Siedlecki później Zawodzińskiemu ${ }^{85}$.

Także $z$ powodu zwlekania Tuwima jego nazwisko nie znalazło się $\mathrm{w}$ słynnej księdze ku czci Wóycickiego. Nie wiadomo, czego konkretnie miała dotyczyć rozprawa poety - może teorii przekładu poetyckiego, może zagadnienia interesującej go wówczas poezji dziecięcej, może zaś problematyki poruszanej w książce Pegaz dęba, czyli Panopticum poetyckie. Z listu Siedleckiego do Kridla wynika, że Tuwima zaproszono do współpracy dość późno, nadto miał on „przerobić swój Czterowiersz, a nie przerobił go wcale”, toteż ostatecznie sam redaktor, zmuszony ciąc koszty, zaproponował Kridlowi zrezygnowanie z usług autora Biblii cygańskiej ${ }^{86}$. Niezależnie od tych niepowodzeń wypada docenić sam fakt, że Siedlecki zaprosił poetę do współtworzenia publikacji mającej stanowić, bądź co bądź, wizytówkę nowej nauki o literaturze (a poeta wstępnie się zgodził) ${ }^{87}$.

$Z$ Tuwimem bez wątpienia łączyło młodego badacza zainteresowanie teoria przekładu $^{88}$. Wprawdzie sam Siedlecki zajmował się tekstami eseistycznymi i naukowymi, ale zasłyną jako krytyk tłumaczeń poezji rosyjskiej na język polski ${ }^{89}$, był także pierwszym czytelnikiem i komentatorem translacji Chlebnikowa i Nikołaja Gumilowa, wtedy twórców prawie w Polsce nieznanych ${ }^{90}$. Najistotniejsze wydaje sie jednak nie to, że i Siedlecki, i Tuwim przekładali teksty obce na polski, ale że przekładali teksty - rosyjskie. Fascynacja ówczesną kultura wschodniego sąsiada skłaniała badacza i poetę do czytania tych samych książek, polecania sobie nowych autorów i wymieniania się ich tekstami, zdobywanymi różnymi kanałami. Prawdopodobnie nie dowiemy się, skąd w 1936 roku Siedlecki posiadał brneński adres zamieszkania Jakobsona ${ }^{91}$, nie jest natomiast wykluczone, że zdobył go właśnie od Tuwima, który osobiście poznał uczonego w 1929 roku w Pradze i z którym później korespondował ${ }^{92}$. Pewne jest zaś to, że w grudniu 1936 Tuwim pytał

Sie d le cki, list do Zawodzińskiego.

F. Siedlecki, list do M. Kridla, bez daty. Lietuvos mokslu akademijos Vrublevskiu biblioteka. Rankraščiu skyrius, F. 115, vnt. 271, lap. 4.

W księdze znalazło się nadto miejsce dla artykułu innego poety, Podhorskiego-Okołowa, o rymowankach dziecięcych.

Twierdziła tak również A. O b r ę b s k a - J a bł oń s ka (list do K. Nitscha, z 26 VI 1945. Archiwum Nauki PAU i PAN, K III-51, j. 192 d).

F. Sie dle c ki, Przekłady z poezji rosyjskiej (1936). W: Pisma, s. 663-675.

Z nowej liryki rosyjskiej. Red., przekł. S. Polla k. Warszawa 1936.

Zob. F. Si e d le c ki, list do W. Grodzieńskiej i S. Pollaka, z 24 IV 1936.

R. J a k ob s o n, list do J. Tuwima, z 13 IV 1929. Muzeum Literatury im. A. Mickiewicza w War- 
Siedleckiego, czy ten „nie ma czego ciekawego nowego” z poezji rosyjskiej, na co młody badacz zadeklarował dostarczenie zaprzyjaźnionemu poecie wszystkiego, co zgromadził w swojej domowej bibliotece ${ }^{93}$.

A co mógł przynieść Tuwimowi? Czy wspomniana już, wydaną w tym samym roku, antologię tłumaczeń Pollaka z nowej liryki rosyjskiej ${ }^{94}$ ? Chciałoby się wierzyć, że tak, skoro rok później Siedlecki zachwycał się nowym wierszem Tuwima (Jeleń), zastanawiając się nad jego powinowactwem $z$ twórczością rosyjskiego futurysty: „złudzenie czy też rzeczywiście z Chlebnikowa?"95. Chyba nie złudzenie. Tuwimowski opis pochodu rogacza po lesie rozpoczyna się od słów: „Stuk po lesie, a nie dzięcioła, / I nie siekier, a stuk po lesie: / Mglisty jeleń na tacy czoła / Stukające gałęzie niesie"96. Także u Chlebnikowa można znaleźć podobne motywy: tego samego, zwierzęcego bohatera („Gdy rogi jelenia wznoszą się nad zielenią, / Wydają się wyschniętym drzewem" ${ }^{97}$ ), jak również nawiązania do słowiańskiej mitologii i łączącej się z nią mistyki, która to sfera jest u Tuwima reprezentowana przez „drzewodziejów”, „szaromary” $i$,nieistoty”, obudzone stukotem jelenia i podążające za nim do „wielkiego ołtarza”, gdzie „poklękały dymiące mgliska”. Inspirowane Chlebnikowem wydaje się zwłaszcza to, że akcja czterostrofowego utworu rozpoczyna się dźwiękiem (,stuk po lesie”), a kończy mistycznym przebudzeniem całego lasu i jego mieszkańców - nie słowo jest tu więc na początku, lecz głos. W ostatnim wersie - podobnie jak w liryce rosyjskiego poety, który układał całe wiersze $\mathrm{z}$ zapisanej „mowy” ptaków - dźwięk zahaczania porożem o gałęzie drzew zyskuje rangę sztuki, rogi zwierzęcia zostają bowiem określone mianem „harfy jeleniej” 98 .

Widziana w świetle wspólnych fascynacji kulturą rosyjską, rola Siedleckiego w biografii twórczej Tuwima zdaje się mieć niebagatelne znaczenie. W 1950 roku Jan Lechoń, bodaj nie bez intencji krytycznej, zwracał uwagę: „Nikt dotychczas nie napisał, że Tuwim w całej swej od piętnastu lat przynajmniej poezji jest przykładem w pływu poezji rosyjskiej na polską"99. Jeśli wierzyć, że od 1935 roku Tuwim silnie inspirował się liryką rosyjską, to w takim razie należy podkreślić, iż wspierał go w tym także m.in. Siedlecki. Przypomnijmy, że Tuwimowi dedykował esej z 1939 roku poświęcony książce Kornieja Czukowskiego o mowie dziecka ${ }^{100}$; posiadał oryginał tej publikacji i zapewne podją dialog o niej z poeta, który w dru-

szawie. Dział Rękopisów, nr inw. 3075, t. 11. Zob. też J. Tuw i m, list do A. Bema, z 20 X 1936. Archiwum Alfreda Bema. Literárni Archiv Památniku Národniho Písemnictví, Praha. Cyt. za: P. Mitzn er, Obcy wśród obcych. Julian Tuwim i rosyjscy emigranci. „Acta Universitatis Lodziensis. Folia Litteraria Polonica” 2014, nr 4, s. 130.

F. Si edlecki, list do W. Grodzieńskiej i S. Pollaka, z 13 XII 1936.

Zob. przypis 90 .

Si e d le cki, list do Grodzieńskiej i Pollaka, z 1 I 1938.

J. Tuw i m, Jeleń. „Wiadomości Literackie” 1938, nr 2, s. 1.

W. Chle b n i k ow, [Gdy rogi jelenia wznosza się nad zielenią...]. W: Włamanie do wszechświata, s. 53 (przeł. A. Kamieńska, J. Ś piewak).

Tuw im, Jeleń, s. 1.

J. Le ch oń, list do M. Grydzewskiego, z 16 II 1950. W: M. Grydzewski, J. Lechoń, Listy 1923-1956. Z autografu do druku przygot., wstępem i przypisami opatrz. B. D o r o s z. Warszawa 2006. T. 1, s. 302-303. Cyt. za: A. S o bi e s k a, Wokół Aleksandra Błoka. Z dziejów polskiej fascynacji kultura i literatura rosyjska. Warszawa 2015, s. 61.

Zob. przypis 66. 
giej połowie lat trzydziestych $\mathrm{XX}$ wieku pisał swoje najsłynniejsze teksty dla dzieci.

Oprócz twórczości Błoka, Chlebnikowa czy autora rozprawy Od dwóch do pięciu lat i Tuwim, i Siedlecki prawdopodobnie inspirowali się gniewna, wulgarno-kolokwialna poezją Majakowskiego, której echa widoczne są w słynnym Balu w operze, bardzo cenionym przez młodego badacza („Czy zdajesz sobie sprawę, że to jest synteza całego naszego życia, naszej epoki?”, mówił z przejęciem Pollakowi $\left.{ }^{101}\right)$. Zarówno w pisarstwie poety, jak i teoretyka pojawiały się wyraźne akcenty ostrej krytyki społecznej, miejscami przybierającej odcień publicystyczny i wywołanej głębokim rozczarowaniem. W twórczości Tuwima najpełniejszym wyrazem tego rozczarowania jest tekst znany pod tytułem Całujcie mnie wszyscy $w$ dupę, w którym obrywało się każdej grupie: „katowickim węglokopom”, „lodzermenschom, byczym chłopom”, „warszawskim bubkom, żigolakom / Z szajką wytwornych pind na kupę”, a także „syjonistkom palestyńskim” oraz „wszechsłowiańskim marzycielom” ${ }^{102}$. Warto czytać ten wiersz - nie piszę „satyryczny”, bo poeta dawał w nim upust frustracji wywołanej gęstniejącą w międzywojniu atmosferą antysemityzmu - równolegle do szkicu Siedleckiego o radzieckiej literaturze dla dzieci, który to tekst, przez samego autora określany jako „opowiadanie” 103 , opublikowano rok wcześniej i bez watpienia znał go Tuwim. Odnoszę wrażenie, że charakteryzując typowych autorów literatury dziecięcej, przeciwstawianych w eseju m.in. Czukowskiemu, Siedlecki mimochodem dał wyraz rozczarowaniu polskim społeczeństwem jako takim:

„Nieudaczniki”, bankruci, pechowcy, których zawiodła kariera beletrystyczna, belfrzy-śledziennicy, tępi doktrynerzy-pedagodzy, zdurniałe oderwane od życia hemoroidalne pismaki-biuralisty, nobliwe przeraźliwe dziewice-dyplomantki (złoty medal „Instituta Błagorodnych Diewic”), cichcem wyżywające się w „powiastkach dla panienek” kryptoerotomanki, panny garderobiane i groźne apostołki miłości i filantropii, bezpłciowe rozestetyzowane rozlazłe flaczki, anemiczne kanarki, uroczo szczebiocące w wyzłacanych klateczkach wonnych buduarów [...] - oto były kadry autorów literatury dziecięcej ${ }^{104}$.

Sam Tuwim by się nie powstydził... W tym dosadnym pamflecie na całe społeczeństwo łatwo przeoczyć ideologiczny fundament, na którym opiera się ciężar krytyki. Jest nim postrzeganie rzeczywistości społecznej z klasowego punktu widzenia, co w przypadku komunizującego, pozbawionego perspektyw zawodowych i żyjącego prawie w nędzy Siedleckiego nie może dziwić. Szeroko rozumiana problematyka socjalna uwydatnia się już w początkowych wersach jego poematu dla dzieci („Babie lato! Złota jesień! / Co za spokój w krąg ogromny!... / Lecz cóż jesień ta przyniesie / Bezrobotnym i bezdomnym?..." ${ }^{105}$ ). Natomiast ściśle pojmowana kwestia świadomości klasowej, alienacji, wpływu rewolucji na literaturę i klasowego podłoża estetyk są jednym $z$ głównych tematów najobszerniejszego, nie licząc studiów wersologicznych, tekstu Siedleckiego, czyli publikowanego w odcinkach,

102

02 go $w$ dupe pocałowali (1937). W: Dzieła. Jarmark rymów. Red. J. W. G o muli cki. Warszawa 1955, s. 291.

103 F. Siedlecki, Głos spod pręierza (1936). W: Pisma, s. 631.

104 F. Si e d l e c ki, Wielka literatura dla małych (1936). W: jw., s. 622.

105

Siedlecki, Muzykantów było sześciu, s. 77. 
w „Skamandrze” i „Sygnałach”, nigdy nie wydanego łącznie, eseju biograficznego Fragmenty o Błoku (1937-1938) ${ }^{106}$ (a precyzyjniej mówiąc: „opowieści biograficznej”, ponieważ zarówno formą, jak i ideą nawiązującego bodaj do Nurtu 〈1934〉 i do Diogenesa $w$ kontuszu 〈1937〉 Wacława Berenta). Nie doceniano tego utworu, moim zdaniem, nie tylko dlatego, że w świadomej stylizacji dopatrywano się „rozpoetyzowania" samego autora, lecz także $z$ tej racji, że nie dostrzegano wymiaru społeczno-klasowego ${ }^{107}$. Toteż Fragmenty... zasługują na osobne omówienie.

\section{Esej nie tylko o Błoku}

Pobieżna lektura pierwszej części eseju, zatytułowanej Dziewięćset piąty, mogła tworzyć mylne wrażenie o Siedleckim jako epigonie prozy symbolistycznej, który ociera się o granicę grafomanii. Charakteryzując środowisko rosyjskich symbolistów z okresu przełomu wieków, autor rekonstruował ich postawę wobec twórczości na pozór bez dystansu: „Tajemne jej [tj. rzeczywistości] znaki odczytywać z płatka róży, z grzmotu wodospadu, z głosu ptaka. [...] Być harfą łkającą w bólu i tęsknocie za Niecielesnym, które się kiedyś ucieleśni. Opowiadać o Nadchodzącym. Zwiastować. Oczekiwać" ${ }^{108}$. Nie trzeba być wielce wytrawnym czytelnikiem, by dostrzec w tych słowach Flaubertowską, przeszytą ironią narrację personalną, ukazującą światoodczucie rosyjskiego symbolisty i ziemianina, całkowicie wyzbytego świadomości własnego uprzywilejowania i przez to „odklejonego” od rzeczywistości. Autor sygnalizuje to wprost w partiach tekstu, w których perspektywa personalna ustępuje na chwile auktorialnej - i wówczas rosyjskie ziemiaństwo zostaje ukazane jako „olśniewająco bogate, lecz już chorobliwie wypaczone, niosace na sobie i w sobie piętno zagłady” 109 . Albo kiedy mimochodem wtrąca, że symboliści pisali „mętne, puste artykuły"110. Lub gdy z szyderczą ironią wytyka naiwność żonie Dmitrija Mereżkowskiego, stwierdzając, że „Z narzuconym na arystokratyczne wąskie ramiona bezcennym szalem, pani domu, mądra wyrafinowana poetessa - Zinaida Gippius z lekkim zniecierpliwieniem czekała na rewolucję"111. Sygnały dystansu do symbo-

Wbrew informacji ze słownika biobibliograficznego (Wspótcześni polscy pisarze i badacze literatury. Stownik biobibliograficzny. Red. J. C z a ch ow ska, A. Szała ga n. T. 7. Warszawa 2001, s. 247), Fragmenty o Błoku stanowią zamkniętą całość, na którą składają się teksty opublikowane w „Skamandrze” oraz w „Sygnałach”. Podaje je we właściwej kolejności: Dziewięćset piaty („Skamander” 1937, z. 78-80); Dwa fragmenty (.,Sygnały” 1937, nr 27); Aleksander Btok (,.Sygnały” 1937, nr 30); Obrachunki („Skamander” 1937, z. 85-87); List („Sygnały” 1938, nr 40); Droga dalej (,Sygnały” 1938, nr 43).

Jednym z wyjątków jest omówienie J. Ku l c zy c k i e j - S a l o n i (Przegląd prasy. „Życie Literackie” 1937, nr 1, s. 37), towarzyszki Siedleckiego z Koła Polonistów, współtłumaczki tekstów rosyjskich wydawanych w „Archiwum Tłumaczeń z Teorii Literatury”, która chwaliła pierwszą część eseju o Błoku, dostrzegając m.in.: „Autor charakteryzuje podłoże socjalne, na którym zrodził się i wyrósł rosyjski symbolizm, wskazuje powody jego rewolucyjnego nastawienia, które z biegiem czasu przekształca się w ucieczkę od rzeczywistości i zawieszenie w próżni ponad życiem”. 
listów są w samym eseju na tyle oczywiste, że nie trzeba ich szukać poza nim, choć oczywiście można by je wskazać ${ }^{112}$.

Zgodnie $\mathrm{z}$ tytułem, a wbrew pozorom, które stwarzają ironiczne opisy, Dziewięćset piaty jest stylizowanym na literaturę wykładem ukazującym wpływ rewolucji na rosyjską kulturę początków XX wieku. Siedlecki przekonuje, że od oderwanych od rzeczywistości symbolistów, wywodzących się z klasy ziemiańskiej, rzekomo następujący po nich twórcy burżuazyjni, jak Walerij Briusow czy Gumilow, tak naprawdę różnią się tylko pod kątem doboru tematów. Stało się to jasne po rewolucji 1905 roku, obnażającej naiwność polityczną (klasowa) i jednych, i drugich. W konsekwencji wielu autorów podejmowało rozmaite próby ucieczki od rzeczywistości: „Nauczeni smutnym doświadczeniem, jak niebezpieczna jest gra w rewolucję, inteligenci, literaci-symboliści wyzbywaja się z wolna swych zainteresowań społecznych, chłodną ze swego radykalizmu"113. W dalszej perspektywie, zdaniem Siedleckiego, prowadziło to do degeneracji życia literackiego i samej sztuki:

ezoteryczny erotyzm przeradzał się w pornograficzną patologię, w wyrafinowaną perwersję, w skrycie wyuzdaną lubieżność Fiodora Sołoguba, myśl religijna małżonków Mierieżkowskich staczała się w otchłań szarlatanerii mediumizmu i na seansach Jana Guzika wykwintne nerwowe dłonie estetów łączyły się w spirytystycznym kręgu z łapami opasłych burżujek i obleśnych lokajów ${ }^{114}$.

Siedlecki zauważał przy tym, że to, co przed 1905 rokiem stanowiło fundament estetyki zarówno ziemiańskiej, jak i burżuazyjnej, skądinąd ujawniający ich klasową tożsamość - „Odwrócenie się od rzeczywistości, zacieranie jej konturów, dekonkretyzacja jej i symbolistyczne "wyjaśnianie""115 - stało się gwoździem do trumny i przygotowało grunt pod nadejście prawdziwej rewolucji, do której rok 1905 był tylko skromną uwertura.

Na tle gruntownych przemian politycznych i społecznych ukazany zostaje los Błoka; wyrastał on w aurze „rozkwitu symbolizmu rosyjskiego”, lecz był „zbyt silnie związany z rzeczywistością”, by się jej wyrzec dla „mgławicowych fantasmagoryj”" 116 . Błok Siedleckiego jest bowiem skonfliktowany wewnętrznie: nie potępia w czambuł tradycji symbolistycznej, odczuwa sentyment do czasów dzieciństwa i młodości spędzonych w idealizowanym dworku w Szachmatowie, ale wie, że do przeszłości nie ma powrotu. Najpierw nudza go wywody Wiaczesława Iwanowa i nie pociagają modne seanse spirytystyczne, coraz bardziej zaś interesuje poezja Chlebnikowa. Symbolem zerwania stosunków z przedstawicielami własnej klasy jest publikacja wierszy w czasopiśmie redagowanym przez „bosiaka”, Maksima Gorkiego ${ }^{117}$. A później ogłoszony zostaje rewolucyjny poemat Dwunastu.

Bodaj największy dramatyzm udało się Siedleckiemu osiągnąć w części zaty-

Jak np. w polemice z Zawodzińskim, w której Si e dle cki (O swobodę wiersza polskiego, s. 149) przekonywał, że jego oponent ,jest zbyt trzeźwy, zbyt krytyczny, aby na serio brać całą ewangelię Wiaczesława Iwanowa”, petersburskiego towarzysza Mereżkowskich i jednego z ważniejszych symbolistów tego okresu w Rosji.

113 Siedlecki, Dziewięćset piaty, s. 10.

114 Ibidem, s. 11.

115 Ibidem, s. 8.

116 Siedlecki, Aleksander Błok, s. 7.

117 Zob. ibidem, s. 8. 
tułowanej Obrachunki, w której przedstawił proces zyskiwania przez Błoka świadomości własnego uprzywilejowania. W poecie narasta nienawiść do własnej klasy: „Lamentujecie, że poniszczono wam wasze dwory, wyrąbano odwieczne topole, poburzono świątynie?”. Szybko jednak „wynurzała się myśl o własnej winie”118 i Błok, po raz pierwszy spoglądając na siebie oczami dawnego posługacza, dostrzegł złą stronę także swoich wielkopańskich zwyczajów. Jego przemyśleń nie przekreśli zupełnie mające nadejść doświadczenie nędzy i rozczarowanie spustoszeniem, którego dokonali bolszewicy.

Siedleckiego zainteresował więc ten rys biografii poety, który 40 lat później Wiktor Woroszylski (uogólniając tezy rosyjskich krytyków) uznał za dystynktywną cechę inteligencji rosyjskiej, poczawszzy od końca wieku XVIII, a na Błoku i Gorkim skończywszy. Chodzi o charakterystyczną skłonność do „kajania się”, towarzyszącą reprezentantom szlachty, $z$ której w większości wywodziła się rosyjska inteligencja, wyrażającą się w doznawanym i chętnie wyrażanym poczuciu „długu do spłacenia, społecznego długu, społecznego obowiązku i winy; poczucie to ma inteligencja, jest ono poczuciem twórczym, pobudzającym etycznie i estetycznie; to ono kieruje rozmaitymi poczynaniami inteligencji" ${ }^{119}$. Tę samą motywację Woroszylski dostrzegał u Błoka, który w (najpewniej znanym Siedleckiemu) artykule Inteligencja i rewolucja- usprawiedliwiając akt spalenia jego biblioteki podczas rewolucji - kajał sie „nie tylko za winy własnego pokolenia czy pokolenia swych ojców, ale również pokoleń znacznie odleglejszych" ${ }^{20}$. Podobnie w poemacie Dwunastu, zdaniem Woroszylskiego, ogarnął Błoka „nastrój” znamienny dla „wielu inteligentów, którzy zaakceptowali rewolucję nawet wbrew jej odstręczającym realiom, uczynili to zaś w oparciu o najbardziej tradycyjny watek etycznej egzystencji inteligencji rosyjskiej" ${ }^{21}$.

Sądzę, że właśnie ten rys biografii wielkiego poety szczególnie interesował Siedleckiego i sprawiał, iż Błok był mu tak bliski. Nie przypadkiem w Obrachunkach zaciera się granica między cytowanymi wyznaniami samego poety (przełożonymi przez autora na jezzyk polski) a opisami narratora, co nie tylko wskazuje na inspirację Berentowskimi „opowieściami biograficznymi”, lecz także sugeruje kryptoautobiograficzny wymiar tej prozy. Nie zamierzam tu, rzecz jasna, pochylać się nad wciąż nierozwikłanym i niesłychanie skomplikowanym problemem stosunku przedwojennych polskich środowisk lewicowych do sytuacji politycznej w Rosji radzieckiej. Nie sposób już chyba rozstrzygnać, ile Siedlecki faktycznie wiedział o tym, co działo się za wschodnią granica zwłaszcza w latach trzydziestych XX wieku. Pewne jest natomiast to, że $z$ całą mocą krytykował sanacyjną Polske $-z$ jej autorytarnymi i antysemickimi wynaturzeniami, jak też z wpisaną w nią strukturą feudalnego wyzysku i pokładał nadzieję w istnienie lepszego, bardziej sprawiedliwego świata.

Dostrzeżona u Błoka i zarazem symptomatyczna dla inteligenta rosyjskiego postawa „kajania się” wobec „ludu” z cała pewnością nie była równie popularna w kręgach inteligencji polskiej (a i dzisiaj niewiele się pod tym względem zmieniło),

118 Siedlecki, Obrachunki, s. 245-249.

119 W. Woroszylski, Wykład I. 〈O inteligencji rosyjskiej〉. Do druku podał P. Mitzner. „Teksty Drugie" 2019, nr 5, s. 366. 
chyba że w jej lewicowym odłamie, do którego zaliczał się autor Studiów z metryki polskiej, ukształtowany na pismach Stanisława Brzozowskiego i powieściach Stefana Żeromskiego, zwłaszcza zaś na nowych klasykach radzieckich. Toteż w samobiczowaniu Błoka, a także w jego zmiennym, skomplikowanym i ambiwalentnym stosunku do rewolucji, Siedlecki mógł odnajdywać własne rozterki jako lewicowego inteligenta polskiego - nawet jeśli nie wywodził się ze szlachty i przez większość dorosłego życia cierpiał biedę ${ }^{122}$.

Skomplikowany i niejednoznaczny portret Błoka zyskał potwierdzenie także w końcowej część eseju Siedleckiego, stanowiącej refleksję w mniejszym stopniu nad samym poetą, w większym zaś - nad tym, czy jego twórczość może mieć wymiar ponadklasowy. Na pierwszy plan wychodzi Paweł Pietrow (imię i nazwisko zapewne znaczące), „Półdziki prostak, nieokrzesany chłop z głuchej, zapadłej wsi Lipniaki pod Rybińskiem" ${ }^{23}$, któremu wpadły w ręce poezje Błoka. Wpadły w sensie dosłownym - Pietrow znalazł je bowiem najprawdopodobniej w zgliszczach spalonego dworu w Szachmatowie. „W tych czasach analfabeci uczyli się czytać - jak się zdarzyło - na plakatach Majakowskiego, na klasykach greckich. [...] Wplątany w boleśnie rozdartą, wyrafinowaną sztukę Błoka, opętany przez nią, ciemny chamuś Pietrow mocował się, krwawił o nią ręce [...]"124. Historię chłopa z Lipniaków kończy sprzeczka, w którą wdaje się on na pogrzebie poety. W jej wyniku bohater utwierdza się w przekonaniu, że on i jego klasa nie wyrzekną się pamięci o Błoku, choć „droga dalej” będzie niewątpliwie „trudną droga” ${ }^{125}$.

Naiwne, trzeba przyznać, zakończenie opowieści było, jak się wydaje, fikcjonalną dramatyzacją rozterek autora Dwunastu, przeczuwającego „konflikt między jego poezją a tymi, którzy ją będą kiedyś dziedziczyć” ${ }^{126}$. Zarazem jednak celnie zapowiadało sytuację powstała w Polsce Ludowej po 1949 roku, zaledwie kilka lat po śmierci Siedleckiego.

\section{Dwuręczność literaturoznawcy}

Anna Sobieska, badaczka dziejów recepcji Błoka w przedwojennej Polsce, napisała w swej, skądinąd budzącej podziw książce, że Siedlecki pracował nad esejem bio-

Mimo wszystko jednak można w jego biografii odnaleźć elementy świadczące o wyniesionym $z$ domu kapitale społeczno-kulturowym. Uczony w dużej mierze dorywczo (z powodu chorowitości w dzieciństwie i złych warunków bytowych podczas pierwszej wojny światowej), przez ojca - sędziego, a później naczelnika Sądu Grodzkiego - następnie zaś przez wynajętego korepetytora, Siedlecki dobrze zdał maturę i już przed podjęciem studiów posługiwał się kilkoma językami obcymi. $Z$ wypowiedzi Hopensztanda (list do Grodzieńskiej i Pollaka) wynika, że jego dom rodzinny był wyposażony w wielojęzyczną, dobrą bibliotekę („książek w najlepszym gatunku masa”), a ojciec wraz z synami oddawał się rozmowom i przechadzkom po okolicy. Jako znamienne można traktować także to, jak w liście do Pollaków (ibidem), relacjonując pobyt w domu Siedleckich, H o p e ns z t a n d (ironicznie i chyba z aluzją do Mickiewiczowskiego eposu), pisał o ojcu Siedleckiego: „Pan Sędzia radził, bym zabrał kompas, bo inaczej utknę w jakiejś gęstwinie leśnej - a potem troskliwie dopytywał, czy już wróciłem".

Sied le cki, Droga dalej, s. 7.

124 Ibidem.

125 Ibidem.

126

Ibidem. 
graficznym „wbrew zwyczajom” ówczesnych adeptów formalizmu i strukturalizmu ${ }^{127}$. Trzeba zaznaczyć, że to (wyrażone mimochodem) twierdzenie, choć niepozbawione podstaw, przyczynia się do tworzenia nieprawdziwego obrazu przedwojennych literaturoznawców teoretycznych, wśród których „dwuręczny” Siedlecki miałby stanowić wyjątek. Owszem, jeśli jako miarę przyjąc opublikowane teksty literackie w dorobku własnym, to autor Studiów z metryki polskiej może zaliczać się do niewielkiej grupy. Jego przyjaciele z Koła - Żółkiewski, Budzyk, Hopensztand, Stefania Knisplówna - nie ogłaszali drukiem wierszy ani opowiadań, choć już Jan Kott i Ryszard Matuszewski, także członkowie Koła, byli przed wojną poetami, podobnie jak mistrz młodych teoretyków, Wóycicki, który w młodości opublikował poemat Żeglarz. Spośród towarzyszy z kręgu wileńskiego - przed wojną ani Jerzy Putrament, ani Irena Sławińska, ani Maria Rzeuska, ani Kapłanowa (Mayenowa) nie dali się poznać jako literatki i literaci. Od tej strony nie znano również Kridla, choć w jego pośmiertnych papierach znaleziono rękopis dramatu inspirowany Antonem Czechowem i scenariusz do filmu na podstawie Faraona Bolesława Prusa ${ }^{128}$. Niemniej - w tej kalkulacji autorzy dwuręczni nadal pozostawaliby w zdecydowanej mniejszości.

Rzecz jednak nie w tym, komu zdarzyło się opublikować, lepszy czy gorszy, utwór literacki, lecz w przyjęciu komplementarności poznania naukowego i literackiego, cementującego rozliczne w dziejach XX-wiecznej Polski kręgi towarzysko-zawodowe uczonych, poetów i pisarzy. Takim środowiskiem był niewątpliwie „Klub Literacki i Naukowy" ${ }^{29}$, spotykający się w salach Gimnazjum im. Królowej Jadwigi w Warszawie, w którym dyskusje o „kategoriach poetyki formalnej” 130 czy „prądach krytyki literackiej w ZSRR" ${ }^{131}$ podejmowali nie tylko młodzi uczeni, ale także zaproszeni na wykłady krytycy literaccy i poeci.

Wśród nich był Tuwim; jego nazwisko nie znalazło się w końcu w pomnikowej księdze na cześć Wóycickiego, lecz sam poeta relacjonował w liście Alfredowi Bemowi, że jest wprawdzie „dyletantem lingwologii, ale "zapojem" czyta dzieła językoznawcze"132. Przy okazji chwalił Jakobsona (,jaki uczony! jaki "słowowied«!”), znanego mu osobiście i $z$ lektury broszury o poezji Chlebnikowa oraz studium o czeskim wierszu ${ }^{133}$. Żartobliwa metafora Tuwima, zestawiająca nadrabianie wiedzy teoretycznej z długotrwałymi ciagami alkoholowymi, bardzo dużo mówi o jego relacji z wybitnym badaczem. Nie mniej symptomatyczny jest fakt, że Jakobson w Polsce dopiero od niedawna znany także jako poeta i prozaik ${ }^{134}$ - w 1943 roku napisał dla Tuwima wiersz, w którym wyznawał: „Rodzinnej chętnie umknę lianie”, i zachęcał: „Zróbmy burzliwy sabat więc, Tuwimie, / Umoczmy w winie chleb, Ju-

Sobieska, op. cit., s. 155.

Zob. w tej sprawie D. Ulicka, Przegapiona okazja. „Teksty Drugie” 2018, nr 6, s. 227.

Tak nazywało się stowarzyszenie - powstałe po odejściu młodych literaturoznawców ze studenckiego Koła (nie mogli do niego należeć absolwenci) - wedle relacji Si ed le c ki e go (Studia z metryki polskiej, cz. 2, s. 603).

S. Żółki e w ski, list do K. W. Zawodzińskiego, z 1935 (?).

F. Si e d le c ki, list do W. Grodzieńskiej i S. Pollaka, z 6 II 1935.

Tuwim, list do Bema. Cyt. za: Mitzner, op. cit., s. 130.

Ibidem.

R. J a k obs on, Mój futuryzm. Wspomnienia, listy, szkice, wiersze, proza. Przeł. D. Ulicka, Warszawa 2020 . 
lianie / [...] / a nas - tu klnę się na tradycje Lefa - / Pokocha jeszcze czulej panna Stefa" ${ }^{135}$. Jak wspominał autor Poetyki $w$ świetle językoznawstwa, najpierw, w roku 1926, nawiązał z nim kontakt Podhorski-Okołów, jednak to z Tuwimem, poznanym przy lampce tokaju 3 lata później, połączyła go przyjaźn - i to on „z delikatną troskliwością” (i z jakim skutkiem!) nakłaniał uczonego do „wgłębiania się w nienaruszona, gruzłowata problematyke przekładu artystycznego - ulubiony temat Jego ustnych i pisemnych rozważań" ${ }^{136}$.

Naturalnie, relacja $z$ Tuwimem, charakterystyczna dla fenomenu współpracy poetów i uczonych, mającego liczne realizacje w polskiej rzeczywistości powojennej, w biografii Jakobsona nie była czymś niezwykłym, ponieważ już w czasach rosyjskich przyjaźnił się on z Majakowskim i Chlebnikowem i na materiale ich poezji konstruował własna teorię języka poetyckiego. Dla Siedleckiego, który utrzymywał stały kontakt $\mathrm{z}$ poetami, zapraszał ich na zebrania naukowe oraz do udziału w publikacji naukowej, postępowanie Jakobsona niewątpliwie stanowiło wzór do naśladowania.

Wzorem była także jego wszechstronność, czego dowodzi płomienny esej Siedleckiego zaznajamiający czytelnika polskiego z rosyjskim uczonym (dzięki Siedleckiemu dowiedział się o nim np. Zawodziński ${ }^{137}$ ), stanowiący niemal panegiryk na jego cześć, w którym autor zachwycał się tym, że „można ogłosić jednocześnie (w roku 1921) pracę o wpływie rewolucji na język rosyjski i studium o poezji Chlebnikowa” ${ }^{138}$, a także faktem, iż „lingwista Roman Jakobson” opublikował fragment pracy $O$ podstawach filmu czeskiego ${ }^{139}$. W słynnym tekście-oskarżeniu O pokoleniu, co roztrwoniło swych poetów, również omawianym z aprobatą przez Siedleckiego, wolno się dopatrywać głównego źródła inspiracji dla autora Dziewięćset piatego.

To ważne: wszechstronność Jakobsona była przez Siedleckiego uznawana za atut, a nie rozmienianie się na drobne czy przykład dyletantyzmu rzekomego omnibusa, beztrosko wkraczającego na teren cudzych badań. Ograniczenie się wyłącznie do wąskiego obszaru zainteresowań $\mathrm{np}$. wersologicznych, traktowanego jako przestrzeń autonomiczna, oznaczałoby odebranie samemu sobie miana zaangażowanego społecznie intelektualisty, będącego kimś więcej niż tylko specjalistą w danej dziedzinie. Przed zarzutem dyletantyzmu broniło zaś Jakobsona to, że nie próbował w równym stopniu znać się na wierszu, filmie i rewolucji, miał natomiast do perfekcji opanowane pewne ponaddyscyplinowe założenia teoretycznie, których odzwierciedlenia odnajdywał w różnych przejawach działalności kulturowej („nie chodzi Jakobsonowi o czeski wiersz, lecz o gól n o te o r e ty c zn e zagadnienia" ${ }^{140}$ ) i które opisywał w rozmaity, czasem także literacki sposób.

Toteż w podejściu rosyjskiego uczonego, widzianego oczami Siedleckiego, wy-

R. J a k o b s o n, wiersz dla J. Tuwima. Muzeum Literatury im. A. Mickiewicza w Warszawie. Dział Rękopisów. Archiwum Juliana Tuwima. „Curiosa”, nr inw. 3075. Istniejący w rękopisie wiersz, napisany w języku rosyjskim, podaję w tłumaczeniu Przemysława Pietrzaka, któremu bardzo dziękuję.

136 R. J a k o b s o n, List badacza polskiego. „Kultura i Społeczeństwo” 1965, nr 1, s. 15.

137 Zob. na ten temat F. Siedlecki, list do K. W. Zawodzińskiego, napisany między listopadem a grudniem 1934 .

138 F. Si e d le c ki, Roman Jakobson i nowa lingwistyka (1934). W zb.: Pisma, s. 85.

139 Ibidem, s. 87.

140 Ibidem, s. 86. 
kluczone było tworzenie rozgraniczenia na działalność zasadniczą, realizowaną z pełnym oddaniem, i poboczna, traktowana żartobliwie albo po macoszemu. Za każdym razem Jakobson podejmował te same, ogólnoteoretyczne kwestie, ale postrzegane z perspektywy odmiennej problematyki i w świetle innego dyskursu. To właśnie dla Siedleckiego mogło stanowić zasadnicze novum względem obowiązującego w Polsce zwyczaju publikowania „po godzinach”, i czasem pod pseudonimem, „zabaw literackich” (termin Henryka Markiewicza) szacownych na co dzień profesorów, takich jak np. nielubiany przez młodego literaturoznawce „Hrabia na Krakowie Tarnowski" ${ }^{141}$. W tym kontekście warto także rozpatrywać znamienną pogardę, $\mathrm{z}$ jaką Siedlecki wypowiadał się o społecznym postrzeganiu parania się twórczością dla dzieci, w której „zawsze tkwił jakiś lekceważący odcień [...]. [...] Książka dla dzieci robiła się z odpadków, była produktem pobocznym. [...] Pisało się ją lewą ręką"142. Różnodyskursywna twórczość rosyjskich teoretyków stanowiła alternatywę dla tej negatywnie widzianej praktyki, ponieważ likwidowała podział na „prawo-” i „leworęczne” utwory (by nawiązać do metafory Jerome'a S. Brunera), promując w zamian „egalitarny” model pisarstwa dwuręcznego.

Przez pryzmat tych założeń trzeba patrzeć zarówno na relacje między Fragmentami o Błoku a poezja, na której materiale Siedlecki klarował teorię transakcentacji, jak też między esejem o książce Czukowskiego a pisanym mniej więcej w tym samym czasie poematem dla dzieci. Tekst Od dwóch do pięciu lat został zadedykowany Tuwimowi, ponieważ Siedlecki dzielił z poetą fascynację mową dziecka i poezją dla dzieci, ale równie dobrze mógłby być dedykowany Jakobsonowi, który dwa lata później wysłał Siedleckiemu własny artykuł o mowie dziecka i afazji. Autor Studiów $z$ metryki polskiej, wbrew literackiej formie eseju, zajmował się bowiem problematyką dziecięcej mowy w kontekście teoretycznym. Wskazywał na podobieństwo między percepcją utworu poetyckiego, poddawaną dezautomatyzacji, a percepcją charakterystyczną dla dziecka, jeszcze niezautomatyzowana. Pośrednio postulował więc analizę dziecięcej mowy ( $\mathrm{z}$ normatywnego punktu widzenia pełną błędów) $\mathrm{w}$ analogii do analizy twórczości poetyckiej i konstatował, że dopiero zrozumienie języka „małych”, zwieńczone ugruntowaniem jego „obiektywnej poetyki”, może prowadzić do wykreowania takiej literatury dla dzieci, która nie będzie projekcja „zniedołężniałej” perspektywy dorosłego na językową świadomość kilkulatka. Tym samym wykorzystywał wiedzę i dociekliwość teoretyka (co łączyło go z Jakobsonem) $z$ temperamentem twórcy poezji dla dzieci, zainteresowanym sfera praktyczno-warsztatowa (a to z kolei zbliżało go do Tuwima).

\section{Teoretyk versus krytyk: dzieje rozłamu}

M.in. właśnie tak pojęta, inspirowana przykładami rosyjskich teoretyków, idea pisarstwa dwuręcznego stała się przedmiotem gruntownej krytyki ze strony członka warszawskiego Koła, a później Klubu Literackiego i Naukowego, Ludwika Frydego. Siedlecki, który sam nieraz zapalał się w polemice, bywał kilkakrotnie krytykowany na łamach prasy, ale artykuł Frydego wyróżnia się na tym tle po pierw-

141 Siedlecki, Martwa nauka, s. 93.

142 Siedlecki, Wielka literatura dla matych, s. 622. 
sze dlatego, że nie dotyczy wybranej koncepcji teoretycznej bądź konkretnej wypowiedzi, lecz postawy pisarskiej Siedleckiego in toto, po drugie zaś z tej racji, że autorem tekstu o znamiennym tytule Nauka o wierszu czy kiepska krytyka nie był ani przedstawiciel przeciwnego obozu politycznego lub światopoglądowego, ani też reprezentant pokolenia profesorów, temperujących zapędy młodych rewolucjonistów. Był nim natomiast niedawny kolega ze studiów.

Wśród badaczy dziejów przedwojennego literaturoznawstwa w Polsce rozłam $\mathrm{w}$ gronie młodych uczonych, jaki dokonał się w drugiej połowie lat trzydziestych $\mathrm{XX}$ wieku, jest faktem stosunkowo znanym. „Z p. Frydem historia rzeczywiście bardzo przykra, tym przykrzejsza, że to człowiek, z którym długo bardzo dobrze i zupełnie blisko żyłem", żalił się Siedlecki Wyce; on zaś (jak wynika z treści listu) brał go $\mathrm{w}$ obronę ${ }^{143}$. Naturalnie, nie sposób dziś rozstrzygnąć, czy istniały pozamerytoryczne przyczyny ataku na Siedleckiego, czy więc wpływ na relacje dawnych kolegów mogło mieć np. to, że artykuł Frydego, początkowo rozpatrywany jako rozdział księgi ku czci Wóycickiego, ostatecznie - decyzją Siedleckiego - nie znalazł się w niej ${ }^{144}$.

Ważne, że przywoływany tekst był niewątpliwie jedną z przyczyn rozłamu. Zanim doszło do publikacji, Fryde szefował sekcji krytycznoliterackiej Koła, podczas gdy Siedlecki należał do sekcji nauki o literaturze, której przewodniczącym był Żółkiewski. Ale wtedy o sporze nie było jeszcze mowy - wszak po ukończeniu studiów Fryde, wraz z Siedleckim, Żółkiewskim i Budzykiem, stał się współzałożycielem Klubu. Natomiast od czasu zatargu z Siedleckim drogi młodych polonistów rozeszły się - powstała tzw. grupa Frydego, do której należeli m.in. Stefan Lichański, Zdzisław (Libin) Libera, Jan Aleksander Król i Gustaw Herling-Grudziński ${ }^{145}$. Siedlecki publikował w związanych z ulubionymi poetami „Skamandrze” i „Wiadomościach Literackich", a także, podobnie jak Hopensztand, w komunizującym „Lewarze” czy w teoretycznocentrycznym „Życiu Literackim”, natomiast Fryde pisywał do ideowo zależnego od sanacji „Pionu”, jak również do „Tygodnika Ilustrowanego" i „Ateneum”; tuż przed wybuchem wojny założył też, wraz z Józefem Czechowiczem, czasopismo-efemerydę „Pióro”. Wybór miejsca publikacji, rzecz jasna, ujawniał gusta estetyczne. Nie przypadkiem Fryde - który nie cenił Skamandrytów, a wspierał poezję awangardowa - kazał Herlingowi-Grudzińskiemu „przysiegać na świecę”, że ten nigdy nie napisze do „Wiadomości Literackich” ${ }^{146}$. Nadto od „grupy Siedleckiego” różnił odłamowców światopogląd: Fryde „uważał się za liberała, w europejskim znaczeniu tego pojęcia”, co łączył z zainteresowaniem katolicyzmem pojmowanym w duchu Jacques'a Maritaina ${ }^{147}$. Lewicowemu autorowi Studiów z metryki polskiej, przejętemu problemami społecznymi w nie mniejszym stopniu

Siedlecki, list do Wyki.

Sie dle c ki, list do Kridla, bez daty.

Zob. w tym kontekście wspomnienia G. Her ling a - Grudzińskiego (B. Tor uńczyk, Rozmowa z Gustawem Herlingiem-Grudzińskim 〈1982〉. „Zeszyty Literackie”, 9 XII 2019. Na stronie: http://www.zeszytyliterackie.pl/barbara-torunczyk-rozmowa-z-gustawem-herlingiem-grudzinskim/?cli_action=1588066188.3 〈data dostępu: 28 IV 2020)): „Fryde był dla nas rzeczywiście mistrzem, takim, można powiedzieć, rabinem w naszym kółku i jego słowa i opinie były bardzo wiążące" .

Ibidem.

Ibidem. 
niż samą nauką, w pełni odrzucajaccemu rządy sanacji i dostrzegającemu potrzebę gruntownej zmiany politycznej, postawa Frydego niewątpliwie była obca.

Po jednej stronie barykady znalazł się zatem naukowiec wchodzacy w rolę krytyka, po drugiej - krytyk korzystajacy z zaplecza naukowego. Lewicowy, zaangażowany społecznie rusofil, raczej indyferentny religijnie i przy wielu okazjach pokpiwajacy $z$ groteskowych przejawów dewocji, stanął naprzeciw liberała ciepło wypowiadającego się o płynącym do Polski z Francji nurcie katolickiego personalizmu. Wreszcie - wielbiciel poezji metrycznej, przyjaciel Tuwima, starł się z młodym odkrywca i wybitnym mecenasem Awangardy, pozostającej wówczas poza głównym obiegiem życia literackiego. Wszystkie te potencjalne zarzewia konfliktu miały wpływ na dzielący ich spór, chociaż bezpośrednio największe znaczenie zyskał ostatni $\mathrm{z}$ nich.

Warto poświęcić tej debacie osobny namysł, ponieważ doszły w niej do głosu argumenty, które później, po wojnie, będą wielokrotnie powtarzane w nieznacznie tylko zmienionej formie przez inne osoby i w innym kontekście. W dyskusji między Siedleckim a Frydem, liderami swoich „grup”, zarysowały się bowiem - być może po raz pierwszy w tak wyraźny sposób - dwa obozy rywalizujące ze sobą o wpływy w sferze życia literackiego.

Oficjalnie poszło o głośny tekst Siedleckiego, przez Frydego przywoływany bez cudzysłowu ${ }^{148}$, „Likwiduję Peipera”, kontekstowo zaś - o rozprawkę $Z$ dziejów naszego wiersza. Ostra filipika młodego Siedleckiego, który deklarował poparcie dla głównonurtowej poezji Skamandrytów, cenionej prawie powszechnie i dobrze umocowanej na rynku literackim, miała prawo zirytować Frydego, zorientowanego na „kult poezji nowej” i niechętnego wobec zamkniętego przed wojną establishmentu „Wiadomości Literackich” ${ }^{49}$. Linię jego krytyki można zrekonstruować następująco: przede wszystkim Siedlecki nie ma większego pojęcia o literaturze, a wypowiada się na jej temat. Robi to, co gorsza, w majestacie obiektywnej nauki o wierszu, faktycznie jednak wartościujac, czyli uprawiając krytykę. Jego arsenał teoretyka i wersologa jest wykorzystywany do udowodnienia wyższości Skamandra nad poezją awangardowa, reprezentowana przez Peipera. Tego zaś Siedlecki krytykuje, ponieważ go nie rozumie. W rezultacie „unaoczniając niby to walory wersyfikacji tradycyjnej, w gruncie rzeczy pokazuje wartości poezji Skamandra z punktu widzenia jego idei artystycznej”150. Zdaniem Frydego, taka praktyka Siedleckiego, zasłaniającego się autorytetem naukowca, prowadzi do utwierdzenia „starych nałogów” czytelniczych (zamiast wspierać nowatorską poezję):

Cały artykuł p. Siedleckiego służy hodowaniu prymitywnego snobizmu: współczesny pan Jourdain, nie rozumiejący ani nie odczuwajacy poezji, liczy z rozkoszą sylaby akcentowane i nieakcentowane i oblizuje się wymawiając: diareza, lipometria, anapest... [...] Niezadługo usłyszymy o arcydziełach trzynastozgłoskowca, a później o arcydziełach średniówki katalektycznej ${ }^{151}$.

Niewypowiedziane wprost, chociaż wyraźnie sygnalizowane założenie Frydego -

L. Fryd e, Nauka o wierszu czy kiepska krytyka (1937). W: Wybór pism krytycznych. Oprac.

A. Biernacki. Warszawa 1966, s. 135.

Ibidem, s. 139-140. 
który w zakończeniu artykułu doradzał Siedleckiemu „przemyślenie granic swoich kompetencji” i zajęcie się np. napisaniem podręcznika do wersologii, a nie krytyką współczesnej poezji ${ }^{152}$ - stanowi to, że wiedza o literaturze, choćby najbardziej fachowa, nie jest równoznaczna $z$ rozumieniem i umiejętnością właściwej oceny tejże literatury. Siedlecki nie tylko nie powinien uprawiać krytyki ukrytej pod płaszczykiem rzekomo obiektywnej „nauki o wierszu”, lecz także powinien pozbawić się złudzeń, że znajomość najnowszych publikacji wersologicznych z zagranicy daje mu jakikolwiek wgląd w sytuację poezji współczesnej w Polsce.

Właśnie to wydaje się $\mathrm{w}$ tym sporze najbardziej interesujące $\mathrm{z}$ dzisiejszego punktu widzenia. Fryde chciał skrytykować kiepski gust estetyczny byłego kolegi, swoją filipikę musiał jednak oprzeć na solidniejszych podstawach teoretycznych. Dwuręcznemu teoretykowi, krytykowi i literatowi zarzucił więc nieuzasadnione opuszczenie własnego, akademickiego poletka. Nie było innego wyjścia: wobec otwarcie proklamowanego przekonania Siedleckiego o komplementarności poznania naukowego i artystycznego, uzasadniającego „uczoną” szarżę autora Studiów z metryki polskiej na poezję współczesną, jedyną odpowiedzią dyskursywną, którą miał w zanadrzu Fryde, okazało się zajęcie stanowiska akcentującego autonomiczność literatury i nauki. Właśnie dlatego już na wstępie artykułu Fryde zaznaczał, że „pomija stronę naukową" esejów Siedleckiego ,jako niespecjalista” ${ }^{153}$, dawnemu koledze radzi zaś, by na tej samej zasadzie nie uspołeczniał badań naukowych w tekstach krytyczno-popularyzatorskich i nie wychylał nosa poza akademię, do której przynależy. W ten właśnie sposób w sporze między teoretykiem a krytykiem zarysowała się fundamentalna różnica $\mathrm{w}$ postrzeganiu relacji między literaturą a nauką, która powracała wielokrotnie po wojnie, generując spory między literaturoznawcami uprawiającymi krytykę a zawodowymi krytykami.

Patrząc z dzisiejszej perspektywy, można ocenić, że dwaj charyzmatyczni absolwenci warszawskiej polonistyki - obaj na swój sposób naśladujący styl polemicznej argumentacji przywodzacy na myśl pisma Brzozowskiego, o którego zresztą Fryde spierał się z Wyką na łamach prasy i który bez wątpienia był punktem odniesienia dla całego ówczesnego pokolenia młodych krytyków - toczyli po prostu walkę kogutów, wzmacnianą zarzutami ad personam, o wpływy w ówczesnym życiu literackim i o monopol na działalność krytyczna, przy okazji formułując istotne założenia teoretyczne. Jako krytyk większą przenikliwością wykazał się Fryde, który podśmiewał się z przytaczanych przez Siedleckiego przykładów rzekomo wielkiej poezji współczesnej Słonimskiego czy Lieberta, a przyszłość literatury widział w awangardowych utworach Juliana Przybosia, Czechowicza bądź w prozie Witolda Gombrowicza. Fryde miał też słuszność, kiedy dowodził stronniczości Siedleckiego ukrywającej się pod majestatem prawdy naukowej.

Wygląda natomiast na to, że mylił się, sądząc, iż autor Studiów z metryki polskiej był tego nieświadomy ${ }^{154}$. Jak próbowałem dowieść, Siedlecki dobrze zdawał sobie sprawę $z$ własnych ograniczeń poznawczych jako badacza literatury, wiedział, że teoria zawsze jest kształtowana na materiale określonej twórczości i od niej zależy,

154 A taką wyraził sugestię - zob. ibidem, s. 141. 
uczony to zaś także, a może wręcz przede wszystkim, człowiek mający jakieś upodobania, poglądy i awersje. Wspierał się w tym przykładem teoretyków rosyjskich, których przekonanie co do powinności społecznych literaturoznawcy podzielał. Krytyczno-popularyzatorskie eseje wersologiczne, pozostawione w jego dorobku, nie okazały się tak ważne dla krytyki powojennej, jak spuścizna Frydego, ale stanowią za to wyjątkowy w swoim rodzaju (i naśladowany później jako forma wypowiedzi teoretycznej) przykład pisarstwa łączącego dyskursy z pozoru odmienne i autonomiczne.

\section{Epitafium}

„Pamięć komunikacyjna” - by posłużyć się terminem Jana Assmanna - już dawno po Siedleckim wygasła. Bodaj ostatnią bliską mu osobą był Żółkiewski, nieżyjący od 30 lat. Przed 1945 rokiem na gruźlicę zmarło dwóch z trzech braci Siedleckich oprócz Franciszka, także młodszy Jerzy, grafik, poległy podczas obrony Warszawy w 1939 roku. Tuż po wojnie na gruźlicę ciężko zachorował Eustachy, lekarz ${ }^{155}$. W 1963 roku odeszła Stefania „Doda” Knispel-Wróblowa, najbliższa przyjaciółka Siedleckiego, na której rękach „Zgasł” 156 i której udało się ocalić rękopis poematu dla dzieci ${ }^{157}$. Decyzją redaktorów wyboru Pism, poematu tego - podobnie jak „całkiem drobnych notatek, nie mających znaczenia dla problematyki, którą [...] zbiór prezentuje" - nie włączono do książki ${ }^{158}$. Dzisiaj, kiedy redaktorzy nie żyją, chyba nikt nie jest w stanie powiedzieć, gdzie znajdują się rękopis i owe notatki, przez co należy je uznać za zaginione.

Prawdopodobnie nie istnieje już, jeśli kiedykolwiek istniało, archiwum Siedleckiego (w przeciwieństwie np. do archiwum Hopensztanda czy Żółkiewskiego), a większość jego prywatnych dokumentów spłonęła w pożarze kamienicy, gdzie mieszkał do śmierci, podczas powstania warszawskiego. Nawiasem mówiąc, dzisiaj po tym budynku nie ma śladu - pod przedwojennym adresem Dobra 96 mieści się pusty betonowy plac, relikt po nieuczęszczanym już chyba przyszkolnym boisku do piłki nożnej. Nie ma też wieści o rodzinnym grobie Siedleckich na warszawskich Powązkach, gdzie wedle relacji Budzyka pochowano autora Studiów z metryki polskiej. Dawny kolega $z$ Koła nie podał we wspomnieniowym szkicu - o co trudno mieć pretensje - dokładnego położenia grobu, a parafialne archiwa, w których ta informacja się znajdowała, zostały zniszczone podczas okupacji ${ }^{159}$. Zapytać już

Podaję te dane biograficzne za cytowanym listem Obrębskiej-Jabłońskiej do Nitscha (zob. przypis 88).

K. B u d zy k, Stefania Knispel-Wróblowa (22 XI 1911 - 2 II 1963). Wspomnienie. „Pamiętnik Literacki" 1963, z. 3, s. 257.

Zob. O brębska-J a błoń ska, op. cit. W wydanym po wojnie tomiku wierszy S. Pollak (Godzina życia. Poezje. Łódź 1946, s. 35-36) zadedykował przedwojennym przyjaciołom, Knispel-Wróblowej i Siedleckiemu, po jednym wierszu (List do przyjaciela i Dickens).

[S. Żółkiewski, M. R. Mayenowa], Nota wydawnicza. W: Siedlecki, Pisma, s. 691.

Informacja zawarta pod napisanym przez R. Żebrowskiego hasłem Franciszek Siedlecki w Polskim słowniku judaistycznym (Red. Z. Borzy mińs ka, R. Żebrows ki. T. 2. Warszawa 2003, s. 528), przedrukowanym na stronie internetowej Żydowskiego Instytutu Historycznego, stanowiąca, że Siedlecki rzekomo „Ukrywał się po "stronie aryjskiej"” podczas okupacji, mogłaby rodzić uzasadnione wątpliwości co do pochówku uczonego na warszawskich Powązkach. Podsta- 
chyba nie ma kogo. Gdzieś więc Siedlecki spoczywa, zapewne nieopodal miejsca, w którym o nim piszę (warszawski Żoliborz), ale nie wiem dokładnie, gdzie.

Gdy wygasa pamięć komunikacyjna, zaczyna się kształtować pamięć kulturowa - zbiór powszechnie podzielanych wyobrażeń na temat przeszłości, odtąd dostępnej jedynie w formie tekstu. Pisząc ten artykuł, miałem świadomość, iż tworzę portret zmarłego badacza na podstawie strzępów często przypadkowych informacji, jak uwagi wyrażone mimochodem w liście do kolegi albo przeszarżowane stylistycznie passusy z esejów mniej istotnych dla dorobku. Nie twierdzę, że pokazuję Siedleckiego „prawdziwego”, lecz Siedleckiego innego, mniej znanego.

Dlatego na koniec chciałbym pokreślić, iż, wbrew sugestii zawartej w Pismach, list wysłany do Jakobsona w czerwcu 1941 nie był ostatnim słowem Siedleckiego. I nie dowiemy sie już, jak ono brzmiało. Nie jest natomiast tajemnica, że epistoły takie jak ta wysłana rosyjskiemu uczonemu, dopominające się „wyrzeczenia [...] w naukach monograficznych idiografizmu" ${ }^{160}$, Siedlecki popełniał rzadko. W jego korespondencji dominuje ton prywatny, a nie wyżyny metodologicznych abstrakcji. W najpóźniejszym znanym mi liście, skreślonym na miesiąc przed śmiercią, zanotowanym już nie jego „nerwowym, neurasteniczym pismem” i niesygnowanym, zgodnie z jego zwyczajem, nazwiskiem („Fr. Siedlecki”), lecz po prostu: „Franek”, bohater niniejszego tekstu odmawiał przyjaciołom udziału we wspólnej wieczerzy:

Drogi Sewerze! Dziękuję bardzo za pamięć o mojej skromnej osobie i za ponętną propozycję spędzenia Wigilii w tak miłym gronie. Niestety jednak nie będę mógł skorzystać z Twojego zaproszenia, gdyż wyjechać muszę dziś właśnie do Warszawy. Spokojnych życzę Świąt całej Rodzinie, a Joasię [tj. Joannę Pollakównę] aby nawiedził św. Mikołaj z wielkim workiem podarków ${ }^{161}$.

W Dziewięćset piątym Siedlecki dwukrotnie puentował krótkie opisy emblema-

wowa przesłanką wskazująca na to, że Siedlecki mógł podlegać pod nazistowski tzw. paragraf aryjski, jest takie oto wspomnienie Żół ki e w s k i e g o ze wstępu do Pism(O Franciszku Siedleckim, s. 27): „W czasie okupacji początkowo był zatrudniony w biurze epidemiologicznym szpitala żydowskiego na Czystem, a następnie jako sprzedawca w sklepie”. Należy jednak pamiętać, że szpital na Czystem do lutego 1941 znajdował się poza murami getta, a wobec jego personelu najprawdopodobniej nie obowiązywał wówczas paragraf aryjski (zob. B. Engelking, J. Le ociak, Getto warszawskie. Przewodnik po nieistniejacym mieście. Warszawa 2013, s. 287). Zatem biorąc pod uwagę fakt, iż Siedlecki, już od jakiegoś czasu chorujący na gruźlicę, zmarł w lutym 1942, można wnioskować, że prace w szpitalu podejmował najpóźniej właśnie do lutego 1941 (jeszcze zanim szpital przeniósł się do getta), by następnie zatrudnić się na stanowisku sklepikarza i niedługo potem umrzeć. Taki scenariusz wydaje się prawdopodobny tym bardziej, iż w tym samym artykule Żółkiewski zaznaczał, iż Siedlecki zorganizował (oczywiście nielegalna) sprzedaż bimbru, z czego dochód szedł do getta dla zamkniętego w nim Hopensztanda. Wiadomo również, że był - obok T. Kotarbińskiego, Żółkiewskiego i W. Żółkiewskiej - jedną z osób, które, wedle świadectwa Z. Libery, przekazywały do getta „regularnie materiały naukowe, utwory literackie i podziemna prasę”, w tym m.in. fragmenty Kwiatów polskich Tuwima (E n g e l ki n g, Le o c i a k, op. cit., s. 580). Również zachowane w Archiwum Uniwersytetu Warszawskiego dokumenty po Siedleckim, takie jak świadectwo maturalne (z 1929 r.), nie zawierają wskazówki, że Siedlecki musiał ukrywać się po tzw. stronie aryjskiej ze względu na swoje pochodzenie (Archiwum Uniwersytetu Warszawskiego, 651 - 1442016 teczka RP 30.495). Za konsultację w tej sprawie bardzo dziękuję prof. J a ck o wi Le o cia k ow i. Sied lecki, list do Jakobsona, s. 78 .

161 F. Sie dle cki, list do W. Grodzieńskiej i S. Pollaka, z 24 XII 1941. 
tycznych dla kultury rosyjskiej scen słowami: „Taki był ten rosyjski symbolizm” 162 . Teraz chciałoby się, jego wzorem, napisać: taki był ten Franciszek Siedlecki.

I taki był ten polski strukturalizm.

\author{
Abstract \\ ARTUR HELLICH University of Warsaw \\ ORCID: 0000-0002-0748-1834

\section{THE VIVACIOUS SCIENCE OF FRANCISZEK SIEDLECKI}

The article examines the work of an eminent Polish literary scholar, structuralist, versologist, essayist, and poet Franciszek Siedlecki, who died prematurely in 1942. The author claims that Siedlecki's oeuvre taken only as a whole, unseparated into scientific studies, essays, poems, and letters-can be considered as a model of the modern literary theory scholar's life and work. This is because of Siedlecki's being "betwixt and between" in two meanings: literature and literary studies, and between science and politics, where both meanings are dependent on each other. The "double-handed" writing, proper for the modern literary theory studies, as the author argues, apparently can and d o es have a clear political and social dimension.

The analysis takes into account mainly the less known or even unknown texts by Siedlecki-essays published in prewar periodicals as well as his letters found in the archives in Warsaw, Vilnius, and New York-and treats them as counter-narratives that splinter the widely accepted beliefs about both Siedlecki's legacy and the origins of Polish structuralism, undermining the allegedly autonomical status of the latter. Seen this way, Siedlecki also today is becoming a surprisingly interesting scholar and writer. 